LUCAS ALÉCIO GOMES

\title{
Estudo morfológico da glândula pineal no cão
}

Dissertação apresentada ao Programa de Pós-graduação em Anatomia dos Animais Domésticos e Silvestres da Faculdade de Medicina Veterinária e Zootecnia da Universidade de São Paulo, para obtenção do título de Mestre em Medicina Veterinária.

Departamento:

Cirurgia

Área de Concentração:

Anatomia dos Animais Domésticos e

Silvestres

Orientador:

Prof $^{a}$. Dr. ${ }^{a}$ Irvênia Luiza de S. Prada

São Paulo 
Autorizo a reprodução parcial ou total desta obra, para fins acadêmicos, desde que citada a fonte.

DADOS INTERNACIONAIS DE CATALOGAÇÃO-NA-PUBLICAÇÃO

(Biblioteca da Faculdade de Medicina Veterinária e Zootecnia da Universidade de São Paulo)

T.1288 Gomes, Lucas Alécio

FMVZ Estudo morfológico da glândula pineal no cão / Lucas Alécio Gomes. -- São Paulo : L. A. Gomes, 2003.

$81 \mathrm{f}$ : : il.

Dissertação (mestrado) - Universidade de São Paulo. Faculdade de Medicina Veterinária e Zootecnia. Departamento de Cirurgia, 2003.

Programa de Pós-graduação: Anatomia dos Animais Domésticos e Silvestres.

Área de concentração: Anatomia dos Animais Domésticos e Silvestres.

Orientador: Profa. Dra. Irvênia Luiza de S. Prada. I. Título.

1. Anatomia. 2. Pineal animal. 3. Cães. 4. Microscopia. 


\section{FOLHA DE AVALIAÇÃO}

Nome: GOMES, Lucas Alécio

Título: Estudo morfológico da glândula pineal no cão

Data:

Dissertação apresentada ao Programa de Pós-graduação em Anatomia dos Animais Domésticos e Silvestres da Faculdade de Medicina Veterinária e Zootecnia da Universidade de São Paulo para obtenção do título de Mestre em Medicina Veterinária.

Banca Examinadora

Prof. Dr.

Instituição:

Assinatura:

Julgamento:

Prof. Dr.

Instituição:

Assinatura:

Julgamento:

Prof. Dr.

Instituição:

Assinatura: Julgamento: 
Dedico este trabalho à minha Família;

Dedico também aos nossos irmãos inferiores na escala evolutiva, os animais, que muitas vezes são superiores a nós em seus atos. 
"Sempre considerei um mistério a capacidade dos homens de sentirem-se honrados com a humilhação de seus semelhantes"

Mohandas Karamchand Gandhi

"Mahatma Gandhi" 


\section{AGRADECIMENTOS}

A Deus, por ter-me concedido nova oportunidade na jornada da vida terrestre, para que assim seja possível continuar evoluindo;

À Professora Irvênia, que sem me conhecer aceitou me orientar. Ela não apenas orienta, mas transmite princípios, ensinamentos, valores que nos faz melhorar. Um grande abraço, com muito carinho e fico feliz pela oportunidade de tê-la conhecido. Serei sempre seu aluno, principalmente na escola da vida;

A meus pais, Vila e Cleide, por tudo. Por terem aceitado o desafio e responsabilidade de me criar, por fazer parte de seu lar e pelo maior legado que puderam me transmitir, o qual julgo ser formado por coisas como: amor, caráter, honestidade, princípios que nos aproximam de uma vida mais correta;

À minha esposa, Andréa, pela convivência, paciência nos momentos em que estive ausente enquanto realizei este trabalho, pela ajuda nas situações mais difíceis, e pelo apoio e amor sempre presentes;

À minha filhinha, Eleonora, brilho dos meus olhos, maior alegria da minha vida hoje; assim como para mamãe peço desculpas pelos momentos de ausência. Você me dá forças para tudo;

A meus irmãos, Ana Cláudia, Priscila, Gilberto e Thiago, por ter estado com vocês em nossa infância e adolescência. Pelas brincadeiras de moleque no grande quintal de nossa casa. E por até hoje, sermos unidos por um grande amor. Vocês são muito saudosos. Obrigado por serem meus amigos;

À minha tia Cleidenei Passianoto e meu tio Carlos Gomes, pela ajuda, principalmente quanto ao aspecto financeiro, durante minha graduação, pois sem esse passo não estaria realizando mais esta etapa. Muito obrigado;

Aos meus amigos de Rancharia, Wagner Zoriki, Ives Murata, Alessandro Passianoto (Japonês), Marcelo Coffers (Piper), Sérgio Zoriki, Juliano da Silva (Tonhão), André Gustavo, Elias Neto, Antônio Carlos, pelas vivências escolares e pela amizade verdadeira;

Aos amigos de faculdade, que até hoje estão presentes, Rodrigo Bianchini, Daniel Issao;

Ao amigo especial Henrique Rezende que estendeu a mão no momento que mais precisei, sem impor condições; 
Aos meus amigos Alexandre Mariot, André Filadelpho, Wirton Peixoto, Helder Pereira, Arlei José Birck (Bircão), Carlos Eduardo Bezerra (Cadú), Rafael e Gerson Palhares pela amizade sincera e pelas diversas histórias e gargalhadas que passamos juntos. Vocês irão fazer bastante falta;

Às minhas amigas da pós-graduação Naiane e Karina pela ajuda na colheita do material;

Ao meu sogro, seu Natomi Sonoda, minha sogra dona Estela Dalva e minhas cunhadas lára e Márcia, pela amizade e por toda ajuda principalmente financeira neste período de pós-graduação;

À Profa. Dra. Maria Angélica Miglino pela oportunidade e por aceitar-me como aluno do Curso de Pós-Gradução;

À CAPES pela concessão da bolsa de estudos durante 6 meses;

A todos os companheiros da pós-graduação, pela vivência e ajuda;

Aos funcionários e amigos do Departamento de Anatomia Veterinária, Índio, Jaqueline, Kazue, Ronaldo, Diogo, Patrícia e Maicon;

Ao Prof. Dr. Eduardo Cunha Farias, pela amizade, pelas conversas, pela ajuda na descrição histológica e pela confecção do esquema representando um corte histológico longitudinal da pineal;

Ao Prof. Dr. Francisco Xavier Hernandez Blazquez, pela ajuda na descrição histológica e pela documentação fotográfica;

Aos professores do Departamento de Anatomia da FMVZ-USP;

Ao enfermeiro do setor de clínica médica Milton, pela ajuda e colaboração na obtenção dos animais para que este trabalho pudesse ser realizado.

Ao Centro de Controle de Zoonoses da cidade de São Paulo, pela colaboração quanto à obtenção de animais para nosso estudo.

Ao amigo da pós-graduação Eduardo pela documentação fotográfica quanto à macroscopia e ao amigo Paulo de Holanda-Barros pelas contribuições e sugestões que me ajudaram muito.

A todos os funcionários da biblioteca, especialmente à Cláudia pela paciência e grande ajuda nas correções.

Aos Animais, nossos queridos amigos e irmãos, pelo aprendizado e convivência.

A todos aqueles que tive contato e puderam acrescentar algo de positivo em mim. 


\section{RESUMO}

Gomes, L. A. Estudo morfológico da glândula pineal no cão. [Morphological study of the pineal gland of the dog]. 2003. $83 \mathrm{f}$. Dissertação (Mestrado em Anatomia dos Animais Domésticos e Silvestres) - Faculdade de Medicina Veterinária e Zootecnia, Universidade de São Paulo, São Paulo, 2003.

A glândula pineal animal por muito tempo foi uma estrutura "esquecida" ou considerada de pouca importância para muitos estudiosos ligados à anatomia. Após a descoberta da melatonina, hormônio por ela secretado novas pesquisas e perspectivas surgiram. Neste trabalho, efetuamos estudo morfológico desta glândula no cão, mediante análise macroscópica, mesoscópica e microscópica (microscopia de luz). Para este estudo, foram utilizados 20 cães. A glândula pineal revelou um formato variando de cônico a glossóide (em relação à língua humana); cor entre bege e marrom-acinzentado; consistência gelatinosa. Sua largura e comprimento também foram avaliados e não guardam correlação com o tamanho (comprimento e largura) do encéfalo correspondente. Quanto à microscopia, utilizamos coloração de hematoxilina-eosina e observamos a presença dos seguintes componentes: cápsula; septos ou trabéculas pinealócitos; células da glia; grânulos de pigmentos, não tendo sido registradas a presença de concreções calcáreas.

Palavras-chave: Anatomia. Pineal animal. Cães. Microscopia. 


\begin{abstract}
Gomes, L. A. Morphological study of the pineal gland of the dog [Estudo morfológico da glândula pineal no cão.]. 2003. 83 f. Dissertação (Mestrado em Anatomia dos Animais Domésticos e Silvestres) - Faculdade de Medicina Veterinária e Zootecnia, Universidade de São Paulo, São Paulo, 2003.
\end{abstract}

The animal pineal gland were forgotten for long time by researchers related to anatomy. With the discovery of the melatonin (a hormone secreted by the pineal gland) by Lerner et al., new researches and perspective arises becaming the pineal a structure more investigate. In this work, we studied the morphology of the epiphysis cerebri of the dogs, making a macroscopic, mesoscopic and microscopic (light microscopy) analysis, employing stain of hematoxilina-eosine. We used twenty animals. The pineal reveals a shape that various between conic and glossoid (in relation to human tongue); color between cream and gray-brownish; and a gelatinous consistence. We measured the length and width of the gland and related with the length and width of the respective encephalon. Microscopically the pineal of the dog showed a capsule; septa; pinealocytes; glial cells; pigment granules and no calcareous concretions were observed.

Key words: Anatomy. Animal pineal. Dogs. Microscopy. 


\section{LISTA DE FIGURAS}

Figura 1 Fotografia de encéfalo de cão fêmea, da raça cocker spaniel, com 75 aproximadamente 8 anos de idade, pesando $13 \mathrm{~kg}$. Aumento aproximado de 2,6 vezes. Corte longitudinal dos hemisférios cerebrais, em vista dorsal, destacando-se no círculo a glândula pineal, situada sobre a porção caudal do teto do III ventrículo, com a base inserida na região das habénulas $(\rightarrow)$, evidenciando-se seu formato triangular e ápice projetando-se em direção dos colículos rostrais $(\mathrm{CR})$

Figura 2 Esquema representativo da glândula pineal de cão, em corte 76 longitudinal. $\mathrm{R}$ - recesso pineal do III ventrículo; B- base, $\mathrm{C}$ - corpo e A - ápice da glândula; $H$ - habénulas; $T$ - trabéculas ou septos; $P$ pigmentos, cápsula $(\rightarrow)$.

Figura 3 Fotomicrografia em corte longitudinal da glândula pineal de cão, 77 fêmea, SRD, com aproximadamente 3 anos de idade, pesando 25 $\mathrm{kg}$. $\mathrm{R}$ - recesso pineal do III ventrículo; B- base; C - corpo; A - ápice da glândula; $\mathrm{H}$ - habénulas; $\mathrm{P}$ - pigmentos e cápsula - $\mathrm{C}$. $\mathrm{HE}$

Figura 4 Fotomicrografia em corte transversal de glândula pineal de cadela, 78 SRD, com aproximadamente 13 anos de idade, pesando $11 \mathrm{~kg}$. Aumento de 275,1 vezes. Os pinealócitos (P) mostram-se presentes em todo o parênquima glandular, sendo mais numerosos que as células da glia $(G)$. Os pinealócitos por vezes dispõem-se em arranjo perivascular, em cordão $(\rightarrow)$. HE

Figura 5 Fotomicrografia, em corte longitudinal, de glândula pineal de 79 cadela, SRD, com aproximadamente 3 anos de idade, pesando 25 $\mathrm{kg}$. Aumento de 552,3 vezes. Observam-se pinealócitos (P), células da glia $(G)$ e formação de grânulos de pigmentos $(\rightarrow)$. HE 


\section{LISTA DE TABELAS}

Tabela 1 Medidas do comprimento e da largura dos encéfalos dos cães 79 analisados, expressas em milímetros - São Paulo, 2003.

Tabela 2 Medidas do comprimento e da largura das glândulas pineais, 80 expressas em milímetros, nos cães analisados - São Paulo, 2003.

Tabela 3 Medidas do perímetro das glândulas pineais, expressas em 81 milímetros dos cães analisados - São Paulo, 2003. 


\section{LISTA DE ABREVIATURAS E SÍMBOLOS}

a. C.: antes de Cristo

CCZ: Centro de Controle de Zoonoses

C. E.: comprimento do encéfalo

$\mathrm{cm}^{3}$ : centímetro cúbico

C. P.: comprimento da pineal

d. C.: depois de Cristo

et al.: colaboradores

FMVZ-USP: Faculdade de Medicina Veterinária e Zootecnia da Universidade de São Paulo

H. E.: hematoxilina-eosina

III: terceiro

L. E.: largura do encéfalo

L. P.: largura da pineal

(r) : coeficiente de correlação

SNC: sistema nervoso central

$\mu$ : micrômetro 
SUMÁRIO

1 INTRODUÇÃO

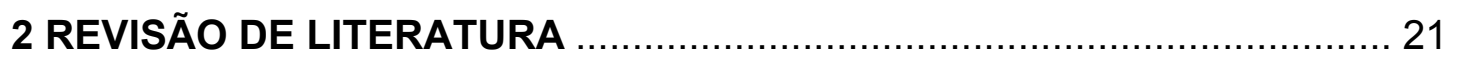

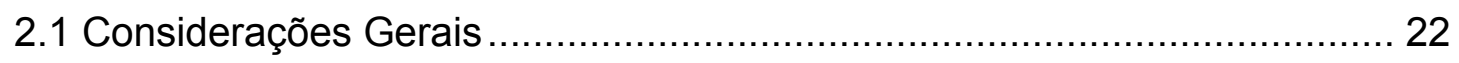

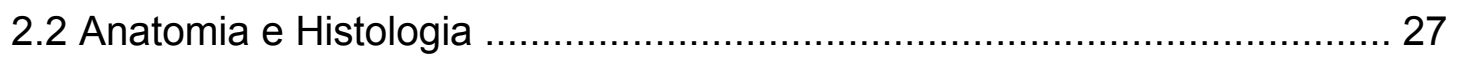

3 MATERIAL E MÉTODO

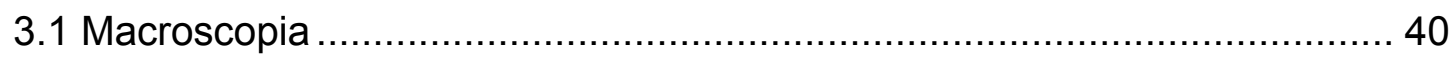

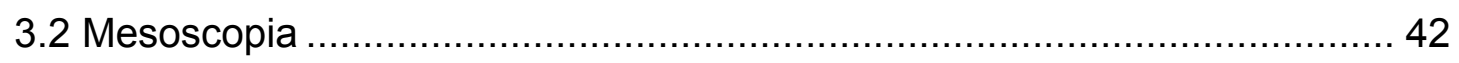

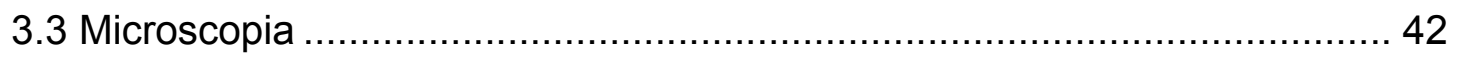

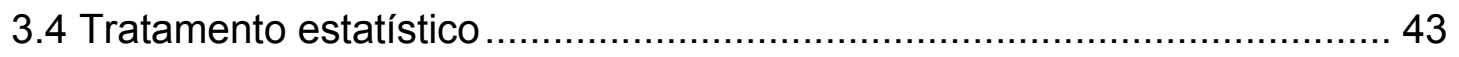

3.5 Documentação fotográfica.................................................................. 43

4 RESULTADOS

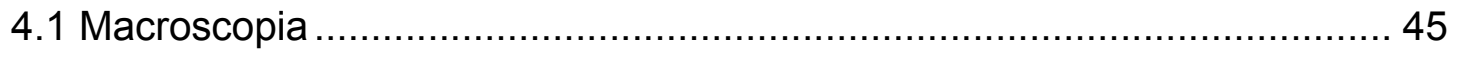

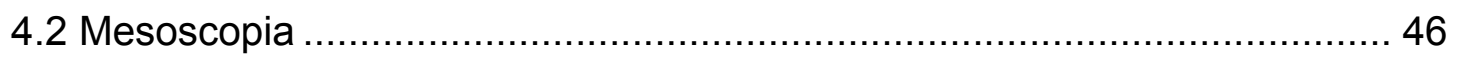

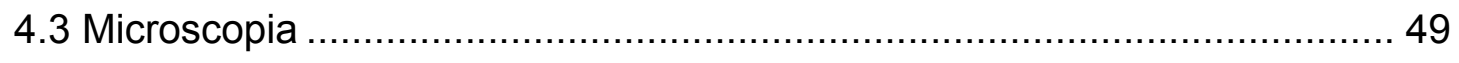

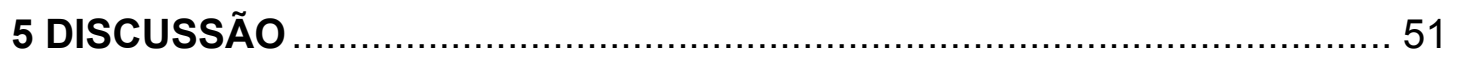

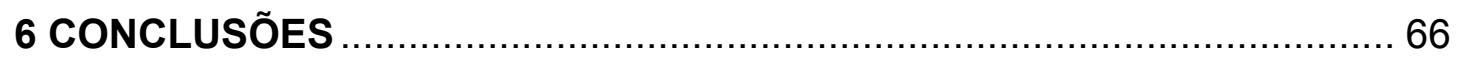

REFEREANCIAS

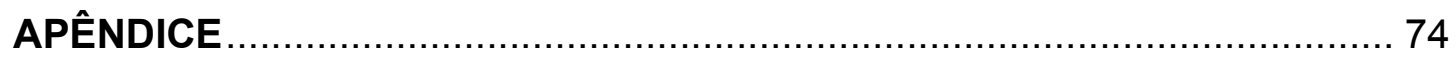




\section{INTRODUÇÃO}

Por muito tempo tinha-se a idéia de que a glândula pineal em vertebrados superiores representava apenas um órgão que sofrera atrofia durante a evolução das espécies, tornando-se um apêndice epitalâmico sem muita função (HOLANDA-BARROS, 2002). Porém, a descoberta, por Lerner et al. (1958), de que a pineal produz um hormônio, a melatonina, abriu um vasto campo para pesquisas relacionadas à sua fisiologia. Este hormônio está envolvido com o controle circadiano e outras funções orgânicas como o ciclo reprodutivo, termorregualção e tolerância termal (TILDEN; HUTCHINSON, 1993). Kitay e Altschule (1954) relatam casos clínicos em que a presença de tumores na pineal em crianças leva a um desenvolvimento sexual precoce do indivíduo, mostrando assim um possível papel antigonadotrófico deste órgão. Reforçando este aspecto, Machado (1993) relata que há um consenso de que pelo menos em mamíferos a glândula pineal tem uma atividade inibidora sobre as gônadas e que em muitos vertebrados e possivelmente no homem participa da regulação dos ritmos circadianos.

Relativo ao histórico da glândula pineal, Binkley (1988) comenta que aqueles que escreveram a sua história não se detiveram apenas a uma cronologia, mas também dividiram-na em épocas. Kappers ${ }^{1}$ (1965 apud BINKLEY, 1988, p. 4)

\footnotetext{
${ }^{1}$ KAPPERS, J. Preface. In: . KAPPERS, J.; SCHADE, P. (ed.). Structure and function of the epiphysis cerebri.,. Progress in Brain Research 10. Amsterdam: Elsevier, 1965. p. IX - XV.
} 
dividiu os avanços nas pesquisas da pineal em três eras, enquanto que Altschule ${ }^{2}$ (1975 apud BINKLEY, 1988, p. 4) sugeriu quatro períodos históricos. Kappers (1965), assim como Altschule

(1975), incluiu na primeira fase o que ele chamou de "noções supersticiosas", idéias

pré-Cartesianas e pós-Cartesianas, a descoberta da glândula pineal e elucubrações sobre a possível função desta (300 a.C. até o fim do século XIX). A segunda era, "estudos preliminares", foi guiada por avanços técnicos em microscopia. Durante este período havia pesquisadores dedicando-se à anatomia, histologia e embriologia comparadas da glândula pineal ( $1^{a}$ metade do séc. $\left.X X\right)$. $\mathrm{Na} 3^{\mathrm{a}}$ era (KAPPERS) ou $3^{\mathrm{a}}$ e $4^{\mathrm{a}}$ eras (ALTSCHULE), com novas investigações houve avanços no campo da fisiologia e farmacologia $\left(2^{a}\right.$ metade do séc. $\left.X X\right)$ da pineal, tendo sido ela funcionalmente relacionada a outras estruturas do corpo. A grande descoberta para estes estudos foi o reconhecimento de que o ciclo de luz e escuridão era um fator importante no mecanismo de funcionamento da pineal. Brainard $^{3}$ (1978 apud BINKLEY, 1988, p. 4) identificou o período de 1954 a 1965 como a "década da transformação" quando "a glândula pineal foi demonstrada como sendo um transdutor neuroendócrino ativo em contraste com a proposta de períodos anteriores em que ela teria uma função vestigial".

\footnotetext{
${ }^{2}$ ALTSCHULE, M. The four phases of pineal studies. In: ALTSCHULE, M. (ed.). Frontiers of pineal physiology. Cambrige: MIT Press, 1975 p. 1 - 4.

${ }^{3}$ BRAINARD, G. Pineal research: The decade of tranformation. In: REITER, J R. WURTMAN, R. (ed.). The pineal gland. . J. Neural Transmission Suppl. 13 New York: Springer-Verlag. 1978. p. 1-20.
} 
Na história da glândula pineal humana, acredita-se que ela tenha sido descoberta por um anatomista egípcio, Herófilos ${ }^{4}$ (325-280 a C. apud BINKLEY, 1988. p. 4), e por um fisiologista em Alexandria, Erasistratus ${ }^{5}$ ( apud BINKLEY, 1988, p.5). Estes indicaram a pineal com a função de uma "torneira" ou "esfincter". Nesta função valvular, a pineal regularia uma corrente de "ar" ou "espírito vital" passando do $3^{\circ}$ para o $4^{\circ}$ ventrículo. Mais tarde, Descartes $^{6}$ (1596-1650 apud BINKLEY, 1988, p. 5) nessa mesma linha de pensamento traria a teoria de que a pineal seria a sede da alma.

O nome pineal deriva de estudos realizados por Galeno (Galeno de Pergamon 130-200 d.C.), no que a considerou sendo uma glândula, separada das demais estruturas encontradas no cérebro. No homem a pineal tem um formato de pinha sendo conseqüentemente, semelhante a um cone, daí surgindo a denominação de conarium (konarion, konareion, soma konoeides). A palavra em latim para esta forma de cone foi pineale (BINKLEY, 1988)

Galeno propôs para a pineal, o papel de uma glândula linfática. Esta idéia foi mudada por cientistas durante o período do Renascimento na Europa (séc. XIV, $\mathrm{XV}$ e XVI) quando muitos aspectos da anatomia, medicina, arte e religião foram abordados com muito interesse.

Binkley (1988) em suas citações sobre os histórico da pineal faz comentário sobre Berengario da Carpi (1460-1530), relacionando este como responsável pela idéia de que a ela filtraria o fluido cérebro espinhal. Segundo este mesmo autor,

\footnotetext{
${ }^{4}$ HOFFMAN, R.; REITER, R Pineal gland: Influence on gonads of male hamsters. Science, v. 148 , p. $1609-$ 1611, 1965,

${ }^{5}$ KAPPERS, J. Inervation of the epiphysis cerebri in the albino rat. Anat. Rec., v. 136, p. 220-221. 1960.

${ }^{6}$ ZRENNER, C. Theories of pineal function from classical antiquity to 1900: A history. In: REITER R. (ed) Pineal research reviews III. New York: Alan R. Liss, 1985 pp 1-40.
} 
Francastor (1483-1553) notou que a pineal era um órgão ímpar no centro do cérebro. Devido a isso ela tornar-se-ia uma candidata para representar o local da coordenação das informações dos órgãos sensoriais pareados (presumivelmente os olhos e orelhas), tendo sido então denominada de sensorium comune. Para o autor, a partir de todas essas idéias é que Descartes pensou na pineal como sede da alma.

Atualmente, a glândula pineal continua sendo uma estrutura muito estudada. Reiter (1981), em relação à nomenclatura da pineal, comenta que o termo epífise cerebral provavelmente seja mais adequado do que glândula ou corpo pineal, uma vez que epiphysis deriva de palavras gregas, sendo que epi significa "sobre" e phyesthai significa "crescer".

Silvino (1999) comenta que todos os conhecimentos sobre a glândula pineal estão embasados em observações funcionais sem, no entanto, indicação clara de suas bases morfológicas, já que as informações da anatomia macro e micoscópica deste órgão são parcimoniosas, quando existentes.

Dyce, Sack e Wensing (1987), em seu tratado de anatomia veterinária relatam que nos animais domésticos a pineal é uma pequena excrescência escuramente pigmentada, situada na extremidade caudal do teto do terceiro ventrículo, imediatamente anterior aos colículos rostrais.

Especificamente quanto à anatomia da glândula pineal no cão, Hullinger (1993), no tratado intitulado Evans Miller's Anatomy Of The Dog, comenta que ela é uma pequena excrescência, ímpar, de coloração creme, em forma de cunha, situada na linha mediana sobre o diencéfalo. Quanto aos aspectos microscópicos da glândula, este mesmo autor comenta que o parênquima da pineal é composto por 
endocrinócitos pineais, envolvidos por neurofilamentos. Há ainda os gliócitos centrais que são células de sustentação. Comenta que a pia-mater promove um limite para o tecido glandular e que moderada quantidade de tecido conjuntivo é encontrado junto à cápsula, seus septos e trabéculas. Por este estroma, cursam vasos sangüíneos e fibras simpáticas pós-ganglionares. Por outro lado, existem dados sobre a anatomia do cão que sequer referem-se à pineal, a exemplo de: Atlas of Canine Anatomy (ANDERSON, 1994) e Microscopic Anatomy of The Dog - A photografic atlas (ADAM, 1970). Em outros casos, trabalhos recentes sobre a ultraestrutura glândula da pineal nesta mesma espécie, a exemplo da publicação de Calvo et al. (1988), tem buscado melhor conhecimento deste órgão, porém deixando ainda uma lacuna no atinente a aspectos de sua anatomia macro e mesoscópica. Talvez o fato de publicações em anatomia não trazerem fotografias sobre a pineal do cão, esteja ligado à própria localização e acanhada representação anatômica desta estrutura. Ellsworth, Yang e Ellsworth (1985) comentam que, no cão, este órgão é difícil de dissecar devido ao seu pequeno tamanho e localização.

Assim, surgiu nosso interesse em enfocar mediante estudo sistemático, tais aspectos, propondo-nos a: mensurar o comprimento e a largura da glândula e do encéfalo; mensurar o perímetro da glândula; efetuar cortes histológicos longitudinais e transversais da pineal.

Com a efetuação desses procedimentos, temos como objetivos:

- melhor conhecer a forma e o tamanho da glândula pineal em cães;

- apurar eventual relação entre suas dimensões e tamanho do encéfalo correspondente; 
- melhor conhecer as estruturas que compõem a glândula pineal;

- contribuir com a literatura sobre o assunto;

- oferecer subsídios para o entendimento do papel dessa glândula, nas diferentes espécies animais. 


\section{REVISÃO DE LITERATURA}

A revisão de literatura foi dividida em dois tópicos:

\subsection{Considerações gerais}

Favilli (1931), em sua publicação Nozione comparate di anatomia e fisiologia degli animale rurali, refere que a glândula pineal ou epífise cerebral possui importância enigmática, sendo considerada por alguns autores como "centro de contato entre o corpo e a alma". Para este mesmo autor, a glândula é um corpúsculo situado entre os tubérculos quadrigêmios anteriores e os tálamos ópticos, sendo que dois pedúnculos anteriores (habênulas) fixam a glândula ao trígono cerebral, dois pedúnculos cerebrais relacionam a glândula com dois pedúnculos médios e dois pedúnculos inferiores com a comissura branca. Segundo Schaffer et al. (1909), a glândula pineal está presente em todos os vertebrados exceto nos anfioxos. Para Creutzfeldt (1912), Krabbe (1916), Murrie (1886) e Vollrath (1981), um órgão pineal propriamente dito está ausente em crocodilianos, edentatas e sirênios, porém células pineais principais sempre são identificadas entremeadas por células gliais, tecido conjuntivo e vasos como um complexo pineal disperso (VOLLRATH, 1981). Para Kappers (1960), é pouco desenvolvida entre os cetáceos, elefantes, marsupiais, roedores e ungulados, sendo ela resultado de uma evaginação da parede dorsal do diencéfalo numa região vizinha à comissura posterior. Relata que alguns pesquisadores têm considerado esta estrutura como vestigial sendo um 
remanescente do olho parietal das formas inferiores. Segundo este mesmo autor, a pineal usualmente possui três tipos celulares, sendo eles: células neurogliais, células parenquimatosas e células espalhadas referentes a células ganglionares não funcionais.

Machado (1993) em seu livro intitulado Neuroanaomia Funcional, relata que a pineal humana origina-se embriologicamente de um divertículo ependimário no tecto do terceiro ventrículo, formando-se assim um saco revestido de epêndima em comunicação com a cavidade ventricular. Segundo este mesmo autor, nos peixes, anfíbios e alguns répteis, este saco permanece como tal e as células ependimárias de sua parede diferenciam-se em fotorreceptores que se assemelham aos cones e bastonetes da retina. Assim, nesses vertebrados inferiores, a pineal é um órgão sensorial que recebe os estímulos luminosos que atravessam a pele e o crânio. Já nas aves e mamíferos, as células ependimárias que formam o divertículo embrionário multiplicam-se, obliterando a luz do divertículo. Estas células diferenciam-se nas células parenquimatosas do corpo pineal ou pinealócitos. Deste modo, durante a evolução, o corpo pineal passou de um órgão sensorial para um órgão parenquimatoso e secretor. Este mesmo autor comenta que em alguns vertebrados inferiores existe, além do corpo pineal, o órgão parapineal, situado próximo à pineal e muito variável. Em alguns lagartos ele constitui o chamado terceiro olho, que é impar e mediano, localizado entre os dois olhos laterais.

Lerner (1962), em tratado sobre endocrinologia humana, comenta que em alguns animais de sangue frio a glândula pineal é um órgão fotorreceptivo, e que seu papel é determinado de acordo com a quantidade de exposição à luz à qual o 
animal é submetido. Refere ainda que em alguns vertebrados inferiores, o aparato pineal é tão diferenciado que parte dele torna-se um olho, o chamado terceiro olho, que não está presente nos vertebrados superiores.

Bargmann (1943) destaca-se entre os autores consultados, não apenas porque tratou da anatomia microscópica do órgão pineal na maioria dos vertebrados, mas também por ter dedicado um capítulo especial para as dependências das estruturas microscópicas da pineal dos mamíferos sobre diferentes condições, internas e externas, a que os animais eram submetidos. De acordo com este autor, o órgão pineal mudou da forma fotorreceptora para um órgão excretor. As células fotossensoriais foram perdendo suas organelas e desenvolvendo dentro dos pinelócitos dos mamíferos estruturas secretoras.

O tratado de Kitay e Altschule (1954) pode ser considerado como um dos mais importantes marcos no estudo da glândula pineal. Neste tratado os autores praticamente resumem, criticamente, todos os fatos sobre a fisiologia da pineal até então publicados, também indicando linhas de pesquisas que se desenvolveram em relação ao referido órgão. Outro acontecimento de grande importância dentro do estudo da pineal foi a descoberta da melatonina por Lerner (1958), o que incentivou ainda mais a nova era de pesquisas sobre esta glândula. O hormônio melatonina (N-acetil-5-metoxitriptamina), produzido na glândula pineal dos vertebrados, está envolvido com o controle circadiano e outras funções comportamentais fisiológicas como o ciclo reprodutivo, termorregulação e tolerância termal (TILDEN; HUTCHINSON, 1993).

Quanto à inervação, Arendt $^{1}$ (1995 apud OLIVEIRA, 1998, p. 3) afirma haver evidências de que a glândula pineal receba múltiplos sistemas de inervação, seja 
de origem exógena, como invervação simpática periférica, seja direta através do sistema nervoso central, uma vez que já fora detectado a presença de neurotransmissores como o peptídeo intestinal vasoativo, arginina-vasopressina, oxitocina, entre outros. Pensava-se que as projeções do SNC iam até o pedúnculo sem atingir a pineal, passando para a comissura posterior, mas a presença dos neurotransmissores na glândula evidencia a inervação central. Constituindo-se no nervo do conário, o único ou duplo, as fibras nervosas periféricas vêm da região da tenda do cerebelo e penetram nas faces dorsal ou dorso lateral da pineal. Estas fibras periféricas simpáticas são originadas nas células do gânglio cervical superior e correm subendotelialmente na parede do seio reto. Esta via parte da retina e pela projeção retino-hipotalâmica atinge o núcleo paraventricular, sendo que este funciona como uma estação intermediária neste circuito. Cipolla-Neto ${ }^{7}$ (1996 apud OLIVEIRA, 1998, p. 4) através de estudo em ratos, comenta que o circuito neuroanatômico responsável pelo controle do metabolismo da glândula pineal, tem uma seqüência que inicia-se na retina, via retino-hipotalâmica, núcleo supraquiasmático, núcleo paraventricular hipotalâmico, fascículo prosencefálico medial, medula espinhal torácica alta, gânglio cervical superior nervos conários e pineal.

Blin e Maurin (1956), em estudo sobre a pineal dos animais domésticos, relatam que ela pode ser classificada baseando-se na sua localização, sendo a região posterior

\footnotetext{
${ }^{1}$ ARENDT, J. Melatonin and the mammalian pineal gland. Ed. Chapman \& Hall, 1995.

${ }^{2}$ CIPPOLA-NETO, J. Controle neural do metabolismo da glândula pineal
} 
do corpo caloso (esplênio), usada como ponto de referência. Assim, as pineais serão supracalosa, subcalosa e pós-calosa. De acordo com esta classificação, a subcalosa é encontrada em carnívoros e primatas, enquanto a posição pós-calosa é presumidamente típica na vaca, no cavalo, no burro, na mula, na ovelha e no bode (BLIN; MAURIN, 1956; FRAUCHIGER ${ }^{8}, 1963$ apud VOLLRATH, 1981, p.12). Reiter (1981), em sua publicação intitulada The Mammalian Pineal Glande: Structure and Function, comenta que a pineal dos mamíferos possui uma ampla variação anatômica e que em virtude disso foram criados vários sistemas para classificar esta estrutura quanto à sua forma, tamanho e localização e que a classificação que parece ter maior versatilidade e aplicabilidade é a que foi proposta por Vollrath em 1981. Vollrath (1981), em seu livro intitulado The Pineal Organ, cita que para Oksche $^{9}$ (1965 apud VOLLRATH, 1981, p. 12) a glândula deve ser classificada apenas pelo seu formato: alongado, cônico ou em forma de pêra. Sendo assim, o autor propõe uma classificação mais completa da pineal tomando como base sua relação com o terceiro ventrículo, envolvendo também a forma e o arranjo do tecido deste órgão. Neste sistema, ele classifica a pineal como tipo proximal ou tipo $A$ se a maior parte do volume deste órgão estiver próxima ao terceiro ventrículo. Se a pineal é alongada, se o comprimento do órgão for em torno de ou ligeiramente maior que duas vezes a maior largura, ela é classificada como tipo próximo-intermediário, designado como tipo AB. Se a pineal é muito longa e uma quantidade substancial de tecido pineal encontra-se relacionado ao cerebelo, ela pertence ao tipo próximo-intermédio-distal ou tipo

\footnotetext{
${ }^{8}$ FRAUCHIGER, E. Altes und neures über die Zirbeldrüse (Epiphysis cerebri) Schweiz. Arch. Tierheilk. v. 105, p. 183-194, 1963.

${ }^{9}$ OKSCHE, A. Survey of the development and comparative morphology of the pineal organ. Prog. Brain. Res. 10:3-29 (1965)
} 
$A B C$. Se qualquer uma dessas partes está substancialmente reduzida em quantidade, as letras maiúsculas são trocadas por letras minúsculas do alfabeto grego. Por exemplo, no tipo $\alpha \mathrm{BC}$, a porção proximal está presente, porém em tamanho reduzido. Se uma região está ausente, a letra correspondente é omitida. Se não existem estruturas delimitadas que permitam a classificação do órgão, esta pineal recebe a sigla de difusa (diff) subscrita após as letras. Se a pineal se encontra dentro do ventrículo recebe a sigla de intraventricular (iv). Se for identificada uma concavidade, como no caso de alguns marsupiais, leva a sigla de côncava (hollow).

\subsection{Anatomia e Histologia}

Dentre os tratadistas de medicina humana, citamos a exemplo Erhart (1968) e Machado (1993), os quais relatam que a pineal humana está localizada na fissura formada pelo encontro do cerebelo e dos hemisférios cerebrais; ela é impar, possui formato piriforme e prende-se às comissuras habenular e posterior. Também Dyson (1995) descreve que a base da pineal humana está posicionada anteriormente e fixada por um pedúnculo dividido rostralmente pela lâmina superior e lâmina inferior, separadas pelo recesso pineal do terceiro ventrículo. As lâminas, superior e inferior, respectivamente contém a comissura habenular e comissura posterior, que são estruturas não endócrinas do epitálamo.

Dentre os tratados de medicina veterinária, quanto à anatomia da glândula pineal podemos citar os seguintes autores: 
Bruni e Zimmerl (1947) no tratado intitulado Anatomia degli animali, descrevem a epífise ou corpo pineal como um corpúsculo alongado, com sua maior porção direcionada caudalmente e para o alto. Sua coloração é rosa-amarronzada, medindo nos mamíferos $8-10 \mathrm{~mm}$ de comprimento, $6 \mathrm{~mm}$ de largura e $5 \mathrm{~mm}$ de espessura. Encontra-se presa ao terceiro ventrículo através de um pedúnculo, o qual abriga o recesso pineal, que nada mais é do que um divertículo do terceiro ventrículo.

Dyce, Sack e Wensing (1987) comentam que nos animais domésticos, a glândula pineal é uma pequena excrescência pigmentada de forma escura, consistência sólida, e é um componente da face dorsal do encéfalo, localizada na extremidade caudal do teto do terceiro ventrículo e imediatamente anterior aos colículos rostrais. No encéfalo intacto, ela situa-se oculta entre os hemisférios cerebrais e o cerebelo.

Venzke (1986), em tratado sobre a anatomia dos animais domésticos, comentam que a pineal está situada na linha mediana, numa depressão entre o tálamo e os colículos rostrais do cérebro e que ela surge inicialmente como uma simples camada de células ependimárias que se desenvolve como uma evaginação do teto do diencéfalo.

Quanto à anatomia da pineal, especificamente no cão, citamos como exemplo o tratado de Evans e Miller (1993), no qual estes autores descrevem a pineal como uma pequena estrutura ímpar, de coloração creme, e que se localiza na região caudal do teto do terceiro ventrículo. Relatam que ela cresce tomando um formato de pólipo e estende-se caudalmente através do espaço existente entre o cerebelo e os hemisférios cerebrais. Estes mesmos autores relatam que o tamanho da 
pineal é de aproximadamente $3 \mathrm{~mm}$ de comprimento, $1,5 \mathrm{~mm}$ de largura e $1 \mathrm{~mm}$ de espessura.

Venzke (1986), no tratado intitulado Sisson and Grossman's Anatomia dos Animais Domésticos, relata que a glândula pineal do cão encontra-se cranialmente aos colículos rostrais e imediatamente caudal ao corpo habenular. Ela é pequena e alongada, em forma de lança e tem coloração cinza-esbranquiçada. No cão adulto tem cerca de $2 \mathrm{~mm}$ de comprimento.

Em trabalho especializado sobre a anatomia da glândula pineal dos mamíferos domésticos, Blin e Maurin (1956) relatam que no cão a pineal é muito pequena e por muito tempo foi ignorada pelos pesquisadores, nesses animais. Comentam que ela possui forma piramidal, consistência gelatinosa e pode variar de coloração quase transparente até rósea e que seu pedúnculo não é visível e seu corpo se une diretamente à comissura habenular. Descrevem que as medidas quanto ao comprimento e a largura são respectivamente de $0,40 \mathrm{~cm}$ e $0,30 \mathrm{~cm}$. Zach $^{10}(1960$ apud VOLLRATH, 1981, p. 17) relata que a pineal no cão mede $3,1 \mathrm{~mm}$ de comprimento e 1,2 $\mathrm{mm}$ de largura.

Em relação a outras espécies, podemos citar Holanda-Barros (2002), que estudou a pineal em 30 serpentes, sendo 15 jararacas (B. jaraca) e 15 cascavéis ( $C$. durissus), e relatou que este órgão apresenta-se como uma pequena estrutura dorsal, mediana, ovóide, de coloração cinzenta ou castanho-escura na região parietal do diencéfalo, ocupando um sulco localizado rostralmente aos lobos óticos e caudalmente aos hemisférios cerebrais.

${ }^{10} \mathrm{ZACH}, \mathrm{B} .:$ Topographie und mikroskopisch-anatomischer feinbau de epiphysis cerebri von Hund und Katze. Zbl. Vet.-Med. v. 7, p. 273-303, 1960. 
Silvino et al. (1992) citam que, em estudos realizados em 30 cutias douradas (Dasyprocta aguti), o órgão pineal foi encontrado em todos os espécimes analisados e apresentou-se alongado, de cor acinzentada ou castanho escuro, situada sobre o teto do terceiro ventrículo, entre os colículos rostrais, ocupando o sulco entre estes.

Branco et al. (1997), estudando a pineal em 19 capivaras (Hydrochoerus hydrochoeris), 3 jovens e 16 adultas, sendo 6 machos e 13 fêmeas, descreve que esta é de coloração branca perolada, às vezes ligeiramente acastanhada, bastante desenvolvida nesses animais. Situa-se no teto do III ventrículo, assentando-se sobre os colículos rostrais e insinuando-se entre o cérebro e o cerebelo. A glândula, nesses animais, apresenta-se constituída por três partes distintas: um ápice mais dilatado, o qual insinua-se entre os hemisférios cerebrais e o cerebelo ultrapassando os limites cerebrais; um corpo cilíndrico mais delgado que serve de conexão entre o ápice e a base do órgão.

Relativo ao aspecto microscópico da pineal humana, podemos citar tratadistas como Szymonowicz e Krauze (1935), relatam que as características estruturais da epífise (glândula pineal) revelam uma função secretora. Descrevem a presença de uma cápsula de tecido conjuntivo revestindo o órgão e emitindo septos para o interior de seu parênquima promovendo uma divisão da glândula em lóbulos de tamanhos desiguais. Nestes encontram-se células nervosas em menor número, os astrócitos, e os pinealócitos como células principais da pineal. Comentam ainda, sobre a presença de depósitos de carbonato e fosfato de cálcio e de magnésio formando estruturas chamadas de areia cerebral, acervuli ou córpora arenácea, estabelecendo uma relação destes com processos degenerativos da pineal. 
Gartner e Hiatt (1999) descrevem que a epífise é revestida pela pia-mater, formando uma cápsula da qual partem septos que dividem a pineal em lóbulos incompletos. Os vasos sangüíneos penetram na glândula através dos septos de tecido conjuntivo. As células parenquimatosas da glândula são constituídas principalmente por pinealócitos e células intersticiais. Esses mesmos autores, ainda comentam que os pinealócitos são células fracamente basófilas, com um ou dois prolongamentos longos, cujas dilatações terminais se aproximam de capilares ou ocasionalmente de outras células parenquimatosas. Seus núcleos esféricos possuem um único nucléolo proeminente. Acredita-se que as células intersticiais sejam da neuróglia, semelhantes aos astrócitos, encontram-se espalhadas entre os pinealócitos e são particularmente abundantes na haste da pineal. Estas células possuem nucléolos alongados, fortemente corados, e retículo endoplasmático rugoso bem desenvolvido.

Yong e Heath (2001) em tratado de histologia relatam que a glândula pineal humana é constituída de dois tipos principais de células: os pinealócitos e as células neurogliais. Os pinealócitos são neurônios altamente modificados dispostos em aglomerados e cordões circundados por uma rica rede de capilares fenestrados, possuem núcleos arredondados com nucléolos proeminentes, citoplasma granular e muitos prolongamentos altamente ramificados, alguns dos quais terminam junto ou sobre os vasos sangüíneos. Quanto às células neurogliais, os autores comentam que elas são semelhantes aos astrócitos do resto do sistema nervoso central, estão dispersas entre os aglomerados de pinealócitos e em associação a capilares. 
Segundo Junqueira e Carneiro (1999), na pineal humana predominam dois tipos celulares, os pinealócitos e os astrócitos. Estas células apresentam-se nas lâminas coradas pela hematoxilina-eosina com o citoplasma claro e grandes núcleos esféricos. Constituem $95 \%$ das células da pineal. A impregnação pela prata segundo o método de Del Rio Hortega mostra que os pinealócitos possuem numerosas ramificações com as extremidades dilatadas. O citoplasma dos pinealócitos contém moderada quantidade de ribossomos, pouco retículo endoplamático rugoso, mas o retículo endoplasmático liso é desenvolvido e o citoplasma contém numerosas vesículas de função desconhecida. O citoplasma apresenta feixes de microtúbulos, mais freqüentes nos prolongamentos. Entre os pinealócitos com seus núcleos grandes e esféricos, observam-se núcleos alongados e mais fortemente corados, que pertencem aos astrócitos. Como tecido nervoso, estes astrócitos possuem prolongamentos e grande quantidade de filamentos intermediários. Os astrócitos constituem $5 \%$ do parênquima da pineal. Cita o autor que, Acervuli cerebri ou areia cerebral, é o nome dado às concreções de fosfato e carbonato de cálcio encontradas normalmente na pineal do adulto e que esta aumenta com a idade. Estas concreções se localizam no material extracelular do tecido conjuntivo. São importantes nos estudos radiológicos, pois tornam a glândula pineal bem visível uma vez que são material radiopaco. A calcificação da pineal não impede sua atividade, porque mesmo na idade avançada, quando o acúmulo de concreções é maior a glândula funciona normalmente, a julgar pelas substâncias ativas e enzimas nela presentes.

Bargman (1961), em seu tratado sobre histologia e anatomia microscópica em humanos, descreve que a epífise é um órgão esférico e conóide, possui uma 
superfície finamente tuberosa e sua base está unida ao teto do terceiro ventrículo através da comissura habenular, ligando-se à lâmina quadrigêmina pela comissura caudal. Segundo este mesmo autor, o recesso pineal do terceiro ventrículo é pouco profundo e penetra na base da pineal. Estudando histologicamente a pineal através do método de Azan, este autor relata que às vezes observam-se territórios semelhantes a lóbulos no interior do órgão e que o tecido epifisário específico é formado por células pineais ou pinealócitos, e células e fibras gliais. Comenta que as células da neuróglia pertencem preponderantemente aos astrócitos, e com o aumento da idade do indivíduo, aparecem processos involutivos como os acervulos ou areia cerebral ou concreções calcáreas, juntamente com degeneração específica do tecido que é representada pelo desenvolvimento de cistos na pineal.

Em relação aos animais domésticos, ainda quanto ao aspecto histológico, podemos citar o tratado de Trautmann e Fiebiger (1950), no qual os autores comentam que a pineal é envolta por um tecido conjuntivo e envia prolongamentos ou trabéculas par o interior do órgão, que são mais ou menos espessas dependendo da espécie e idade do animal, formando uma rede, incompleta no centro. Acompanhando esta rede, há células gliais e agrupamentos de células pineais. Relatam que estas células possuem núcleos claros e volumosos e contém inclusões homógenas, em forma de gotas, que são direcionadas para a periferia e posteriormente atingindo o citoplasma. Pelo pedúnculo pineal, penetram fibras nervosas que cruzam o órgão em todas as direções. Estes mesmos autores relatam que não há células nervosas neste tecido, e que com freqüência se observa um pigmento pardo-enegrecido entre e dentro das células, especialmente 
nos animais velhos. Há também a presença de concreções calcáreas (areia cerebral), corpos amilóides, e nos bovinos, fibras musculares lisas e estriadas em igual quantidade. Comentam ainda, que a glândula pineal não é rica em vasos sangüíneos.

Quanto aos tratadistas que comentam sobre o aspecto microscópico da glândula pineal no cão, podemos citar Hullinger no tratado intitulado Evans-Miller's Anatomy of the dog (1993), o qual através do método de coloração pentacromático, observou que a pineal do cão contém células denominadas de endocrinócitos pineais (pinealócitos), que se encontram em maior número em relação às células de sustentação ou gliócitos centrais. A pia-mater recobre toda a glândula e há uma delicada cápsula que possui moderada quantidade de tecido conjuntivo, e esta envia septos e trabéculas para o interior da pineal. Acompanhando estas estruturas, cursam os vasos sangüíneos e fibras simpáticas pós-ganglionares.

Banks et al. (1986), em seu livro sobre histologia veterinária aplicada, descrevem que a pineal nos animais domésticos é coberta por um tecido conjuntivo da piamater, e que septos e lobulações do órgão são acompanhados por este mesmo tipo tecidual. Em relação aos componentes celulares, os autores relatam a presença de pinealócitos e astrócitos, e eventualmente pode-se encontrar fibroblastos, plasmócitos, mastócitos e macrófagos. Os pinealócitos são o tipo celular predominante e possuem um núcleo aberto, grande e redondo, estando situado em um citoplasma acidofílico. Os astrócitos são típicos e estão situados entre o tecido vascular e os pinealócito. Segundo estes mesmos autores, a pineal contém concreções calcáreas chamadas de corpora arenacea, que parecem ter uma origem glial ou estromal e sua estrutura possui cristais de hidroxiapatita. 
Dellmann e Brown (1982), em tratado de histologia veterinária, comentam que o corpo pineal dos mamíferos mostra-se como um órgão sólido parenquimatoso ou folicular, circundado por uma delgada camada de tecido conjuntivo frouxo. Quanto à celularidade, os autores descrevem a presença de astrócitos circundando os pinealócitos e mantendo um contato com lâmina perivascular, separando assim a maioria dos pinealócitos no espaço perivascular.

Quanto a trabalhos especializados ligados à microscopia da pineal, podemos citar autores como:

Ellsworth, Yang e Ellsworth (1985) em seu trabalho intitulado The Pineal Body of the Dog, estudaram as pineais de nove cães da raça beagle através de histologia empregando como método de coloração a hematoxilina-eosina, descreveram a presença de células ependimárias observadas usualmente na margem, e pinealócitos e células da glia no centro da pineal. Em algumas glândulas, encontrou-se fazendo parte da composição da cápsula, epitélio colunar ou cubóide de um lado e epitélio simples do outro. Estes mesmos autores comentam que não há lobulações e sim grupos de pinealócitos dando origem a formações não bem definidas, semelhantes a ácinos. Estas estruturas são rodeadas por espaços de tecido conjuntivo. Ao redor da periferia da glândula há pequenas arteríolas e no interior há predomínio de capilares. Os processos citoplasmáticos das células da glia e pinealócitos encontram-se próximos aos vasos sangüíneos. As células parenquimatosas não possuem formato uniforme e contém um núcleo vesicular de vários tamanhos com cromatina dispersa, porém de aspecto granular em alguns casos. O citoplasma destas células possui uma coloração rosa claro, com 
prolongamentos às vezes evidentes. Nucléolo único fora usualmente identificado, embora em alguns casos seja duplo. Estes autores ainda descrevem que alguns núcleos escuros foram observados podendo ser linfócitos ou células da glia. Comentam que trabalhos prévios não relataram a presença de concreções calcáreas na pineal do cão e que eles também não encontraram esta estrutura. Como aspecto importante, ressaltam que o tamanho da pineal variou individualmente nos nove cães estudados.

Calvo et al. (1988) realizaram trabalho com 12 cães sem raça definida, sendo todos adultos e de ambos os sexos. Estudaram a estrutura e ultraestrutura das células da pineal do cão, tendo como principal objetivo, avaliar o tipo de pigmento presente nestas células, e mencionam que em 1974 Quay identificou três tipos de pigmentos na pineal dos mamíferos: melanina, lipofuscina e hemosiderina. Para microscopia de luz, estes autores utilizaram o método de coloração de prata de Masson Fontana, e também se utilizou tratamento com hidróxido de hidrogênio e ácido peracético. Neste estudo, encontrou-se pigmento em todas as pineais analisadas pelo método de microscopia de luz e confirmou-se que estes eram de melanina.

Quanto a outras espécies, citamos o estudo envolvendo microscopia de luz, efetuado por de Holanda-Barros (2002), utilizando cinco serpentes jararacas e 5 cascavéis. O autor empregou como método de coloração a hematoxilina-eosina comentando os seguintes achados: presença de uma cápsula composta por epitélio pavimentoso simples, sendo esta bastante vascularizada; células claras com citoplasma preenchido por vesículas, e células mais escuras com núcleos arredondados, variando de esféricos a ovalados, com núcléolos evidentes e 
cromatina frouxa. Estas células na região de ápice dispuseram-se formando ácinos, sendo estes bem delimitados por uma bainha de conjuntivo. Comenta ainda, que a glândula pineal possui uma vesícula que se comunica com o terceiro ventrículo em sua porção ventral, e que esta região é circundada por um epitélio de cúbico a prismático e ciliado.

Silvino (1999), estudando aspectos morfométricos da pineal em 12 ratos machos e 12 coelhos machos, descreve histologicamente que a glândula é revestida por tecido conjuntivo, derivado da membrana encefálica mais interna, a pia-máter, e há uma cápsula que reveste o órgão e emite septos para o interior da pineal. $\mathrm{O}$ parênquima é constituído essencialmente por pinealócitos, com corpos celulares grandes, citoplasma claro e de afinidade acidófila. Seus núcleos são grandes, de forma arredondada ou ovóides, cor escura com cromatina densa ou de cor clara com cromatina frouxa, apresentando um ou mais nucléolos definidos. Comenta ainda, que a presença de vasos sangüíneos, no parênquima glandular contendo hemácias no seu interior foi constantemente observada na região superficial e central do órgão. Relata que a disposição dos pinealócitos mostrou maior concentração na região central do órgão, dando uma idéia de compactação, enquanto que nas regiões superficiais eles apresentam-se mais dispersos dentro do estroma pineal; em algumas áreas os pinelócitos formam cordões distintos. $\mathrm{O}$ autor também descreve a prensença de uma luz central comunicando a pineal com o terceiro ventrículo.

Branco et al. (1997), estudando a glândula pineal em 19 capivaras (Hydrochoerus hydrochoeris), 3 jovens e 16 adultas, sendo 6 machos e 13 fêmeas, empregando como método de coloração para microscopia de luz o uso de hematoxilina-eosina, 
descrevem que órgão é constituído principalmente por pinealócitos, os quais em menor aumento conferem à glândula um aspecto homogêneo e uniforme. Segundo os autores, a base da glândula está inserida através dos seus pedúnculos no tecido nervoso do III ventrículo encefálico. A haste da pineal, porção intermediária entre a base e o ápice, mostra em corte o arranjo do tecido glandular, entremeado a uma série de vasos sangüíneos, alguns mais periféricos e congestos, delimitados juntamente com a glândula por uma fina capa de tecido conjuntivo. Os pinealócitos, de um modo geral, arranjam-se em cordões e concentram-se em determinadas regiões do corte, entremeando-se a vasos sangüíneos, tecido conjuntivo e células neurogliais; possuem citoplasma abundante e núcleos arredondados com condensações de grânulos nucleares.

Carvalho (1997) estudou a glândula pineal de 12 búfalos pelos métodos histológico e histométrico, mencionando também aspectos macroscópicos. Descreveu que ela é grande, de formato globoso, dividida em dois lobos (direito e esquerdo) e situada entre os dois colículos rostrais, coloração bege clara e às vezes, pigmentação escura externamente. Histologicamente relatou que a glândula é revestida por uma cápsula de tecido conjuntivo que se infiltra por todo o parênquima dividindo a mesma em lóbulos visíveis e distintos. O parênquima glandular é constituído em grande parte por pinealócitos e células da glia (astrócitos). O corpo pineal apresentou inúmeras concreções calcáreas, situadas principalmente na região central da glândula. 


\section{MATERIAL E MÉTODO}

Para este estudo utilizamos um total de 20 cães (Canis familiaris - Linnaeus 1758), sendo 14 fêmeas e 6 machos, (14 sem raça definida, 2 pastores alemães, 1 doberman pinscher, 2 dogues alemães e 1 doberman). Desses 20 animais, 12 foram destinados ao estudo macro e mesoscópico e os outros 8 foram utilizados para estudo microscópico da glândula pineal.

Quanto ao local de obtenção dos animais para a pesquisa, 15 deles foram provenientes do Serviço de Clínica Médica da Faculdade de Medicina Veterinária e Zootecnia da Universidade de São Paulo (FMVZ-USP) e os outros 5 animais foram obtidos através do Centro de Controle de Zoonoses (CCZ) da cidade de São Paulo, Estado de São Paulo. Todos os animais foram encaminhados para nosso local de trabalho - Laboratório de dissecção do Departamento de Cirurgia (VCI-FMVZ-USP), já em óbito.

Um pré-requisito para a colheita do material para nossa pesquisa é que os cães envolvidos no estudo não deveriam possuir sinais clínicos ligados a alterações do sistema nervoso central. 


\subsection{Macroscopia}

Para a análise macroscópica, os encéfalos ainda a fresco foram acessados através de uma incisão em correspondência à linha mediana na cabeça, sendo a pele rebatida juntamente com a musculatura da região temporal. Então, com auxílio de uma serra presa em arco (serra utilizada para serrar metal) realizava-se uma abertura na calota craniana em forma retangular envolvendo os ossos frontal e parietal. Esta abertura, em seguida, era ampliada com o auxílio de um alicate. Uma vez exposto, o encéfalo era retirado, preservando-se o máximo possível suas estruturas, desde o bulbo olfatório até a medula oblonga. Os encéfalos foram isolados num período que variou de 20 a 60 minutos após a morte dos animais, sendo então realizada uma incisão correspondente à fissura longitudinal do cérebro para alcançar e seccionar o corpo caloso, separando completamente os hemisférios cerebrais, para uma melhor exposição e contato da pineal com a solução de formoldeído a $20 \%$, na qual foram submersos. O estudo macróscopico somente foi iniciado, depois de um período mínimo de 48 horas em relação à data da imersão dos encéfalos. Em seguida mensuramos o comprimento das pineais e sua largura (tomando como base para esta última medida a porção mais larga da pineal) com um paquímetro eletrônico digital STARRET®, cat. $n^{\circ} 727-6 / 150$, curso $150 \mathrm{~mm} / 6$, "resolução $0,001 \mathrm{~mm}$ E. 0,005 ". Realizamos também com este instrumento as medidas referentes ao comprimento e largura do encéfalo, tomando como parâmetros para estimar o comprimento, a extremidade rostral do lobo frontal e a região de transição entre o bulbo e a medula espinhal e, para a 
largura, o ponto de encontro entre a fissura silviana e o sulco rinal lateral, em ambos os antímeros.

\subsection{Mesoscopia}

Para o estudo mesoscópico das glândulas pineais, foi utilizado um microscópio estérioscópico Zeiss ${ }^{\circledR}$ SM 6 e um microscópio cirúrgico Leika M 651.

Através de uma filmadora acoplada ao microscópio estérioscópico, foi feita a mensuração do perímetro da região dorsal da pineal. A filmadora transferia a imagem para o computador e através do programa software KS400 KontronZeiss ${ }^{\circledR}$, versão 2.0 , número de autorização 0400342, pudemos estabelecer os parâmetros citados.

\subsection{Microscopia}

Para a análise microscópica, os encéfalos foram retirados através do mesmo método utilizado na macroscopia e a colheita da pineal foi realizada num período que variou de 15 a 120 minutos após o óbito.. Uma vez exposta a glândula pineal, procedia-se à retirada de um pequeno bloco em formato cúbico, de tecido do diencéfalo com dimensões de aproximadamente $1 \mathrm{~cm}^{3}$, no qual encontrava-se a pineal. Este material era imediatamente acondicionado em solução de McDowell (paraformoldeído a $1 \%$ + glutaraldeído a $4 \%$ em solução tampão fosfato $0,1 \mathrm{M}$, ph

7.4 mantido em temperatura de geladeira). Após um período de fixação de no 
mínimo 24 horas, este material foi submetido ao procedimento usual de inclusão em parafina. Então foram realizados cortes longitudinais e transversais de $5 \mu$ de espessura e as lâminas foram devidamente montadas e coradas com hematoxilina-eosina para análise em microscópio.

\subsection{Tratamento estatístico}

Foram calculadas as médias e medianas referentes aos resultados obtidos pela mensuração do comprimento, largura e perímetro dos encéfalos e das pineais; foram calculados os coeficientes de correlação (r) entre as variáveis (comprimento e largura) analisadas e aplicado o Teste $-\mathrm{T}$ para verificar se os coeficientes eram diferentes de zero, utilizando-se o programa estatístico Statigraphics 7.0.

\subsection{Documentação Fotográfica}

As fotografias referentes aos aspectos macroscópico e mesoscópico da glândula pineal foram obtidas através de uma câmera digital Sony DSC - F 717 Cyber-shot. As fotografias referentes ao aspecto microscópico foram realizadas em um microscópio Olimpus BX 60. 


\section{RESULTADOS}

Os resultados foram obtidos a partir das seguintes etapas:

\subsection{Macroscopia}

A análise macroscópica foi realizada através das medidas da glândula pineal (comprimento e largura) e do encéfalo correspondente (comprimento e largura) bem como da observação da pineal quanto à sua localização, posicionamento, cor, forma e consistência (Figura 1).

A glândula pineal nos cães estudados apresentou-se situada em relação ao teto do III ventrículo, rostralmente aos colículos rostrais, e na linha mediana em relação ao encéfalo. Sua coloração variou de bege ( 8 animais - $66,66 \%$ dos casos) a castanho-acinzentado (4 animais - $33,33 \%$ dos casos). Sua forma avaliada numa vista dorsal foi predominantemente triangular, o que ocorreu em 12 animais (100\% dos casos). A forma tridimensional das pineais avaliadas foi glossóide (semelhante a uma "língua humana") em 10 animais (83,33\%), sendo que em 2 animais $(16,66 \%)$ ela apresentou-se semelhante a um cilindro, com o ápice terminando em bisel.

A consistência das glândulas pineais estudadas foi gelatinosa em 100\% dos animais analisados. 
O comprimento dos encéfalos variou de $60,15 \mathrm{~mm}$ a $86,27 \mathrm{~mm}$ com média de $70,05 \mathrm{~mm}$ e mediana de 66,64 $\mathrm{mm}$ (Tabela 1$)$.

A largura dos encéfalos estudados variou de $31,31 \mathrm{~mm}$ a 43,48 $\mathrm{mm}$ com média de 36,65 mm e mediana de 36,51 $\mathrm{mm}$ (Tabela 1).

O comprimento das pineais variou de $1,53 \mathrm{~mm}$ a 2,96 $\mathrm{mm}$ com média de 2,05 $\mathrm{mm}$ e mediana de $1,97 \mathrm{~mm}$ (Tabela 2$)$.

A largura das pineais variou de $1,38 \mathrm{~mm}$ a 2,39 $\mathrm{mm}$ tendo média de $1,78 \mathrm{~mm}$ e mediana de 1,69 $\mathrm{mm}$ (Tabela 2).

Tendo sido calculados os coeficientes de correlação $(r)$ entre as variáveis analisadas e aplicado o Teste - $\mathrm{T}$, verificou-se que não há correlação entre as variáveis, ou seja, tamanho do encéfalo (comprimento e largura) e tamanho da pineal (comprimento e largura) correspondente. Os coeficientes de correlação (r) são: $r(C E / C P)=0,0,2131 ; r(L E / L P)=0,1199 ; r(C E / P P)=0,1141 ; r(L E / P P)=$ 0,1289, todos não significativos estatíticamente.

\subsection{Mesoscopia}

Através da análise mesoscópica pudemos observar que as glândulas pineais apresentam formato variado porém, respeitando sempre uma forma padrão que, de modo geral, caracteriza a pineal dos cães. Assim, ela se apresenta de forma cônica ou glossóide (em relação à língua humana), com superfície dorsal tendendo a plana e ventral abaulada, convexa. Dispõe-se com a base inserida na região das habênulas constituindo-se aí estrutura infundibular, uma vez que, 
nessa região acha-se invadida pelo recesso pineal do III ventrículo. Quando observada em vista dorsal, a inserção da pineal na região das habênulas simula, em ambos os antímeros, disposição em pedúnculo. O corpo e o ápice da pineal tendem em sentido dorso-caudal, descrevendo ligeira curvatura de concavidade ventral, em direção à porção mais rostral dos colículos rostrais.

As características assinaladas (corpo, ápice, base e região das habénulas), foram igualmente observadas à microscopia de luz, em corte longitudinal (Figuras 2 e 3). Individualmente, com o auxílio do microscópio cirúrgico utilizado, pudemos observar que algumas das peças mostraram aspectos próprios, que serão comentados a seguir:

1) Macho, SRD, aproximadamente 1 ano de idade, 4 quilos - a pineal neste caso apresentou formato tendendo a cilíndrico, com seu ápice terminando em bisel. Sendo observado em vista dorsal, a porção da pineal inserida na região das habênulas, exibiu sulcos laterais em número de três a quatro, tanto no antímero direito quanto no esquerdo. Por sua vez, dorsalmente o corpo dessa pineal mostrou um aumento de volume localizado, de forma arredondada.

3) Macho, SRD, com aproximadamente 6 anos, $30 \mathrm{~kg}$ - a pineal apresentou formato cônico. Observada em vista dorsal, mostrou superfície plana, com ápice pontiagudo, semelhante a "ponta de lança".

4) Macho, Pinscher, aproximadamente 14 anos, 3 quilos - a pineal apresentou-se em formato cônico, com ápice arredondado. 
7) Fêmea, SRD, aproximadamente 7 anos, $7 \mathrm{~kg}$ - a pineal apresentou-se em formato cônico, com superfície dorsal côncava e ventral abaulada. Em vista dorsal, apresenta formato triangular, entretanto, com ápice arredondado.

8) Macho, SRD, 10 anos, 4 quilos - a pineal apresentou formato cônico, com superfície dorsal revelando uma região central acentuadamente côncava, ápice alongado, fino e pontiagudo.

9) Fêmea, Pastor Alemão, 35 quilos, 6anos - a pineal apresentou formato cônico. Em vista dorsal, apresenta formato triangular e superfície moderadamente abaulada.

10) Macho, Pastor Alemão, 40 quilos, 13 anos - a pineal apresentou formato cônico, tendendo a glossóide (em relação à língua humana). Em vista dorsal, revelou superfície plana, ápice pontiagudo, curvado ventralmente. Na inserção de sua base, na região das habênulas, mostra a presença de três a quatro sulcos, em cada antímero, dipostos em correspondência ao eixo maior da glândula.

11) Fêmea, SRD, 2 anos, 5 quilos - a pineal apresentou formato tendendo a cilíndrico, com seu ápice terminando em bisel. Em vista dorsal, revelou forma tendendo a triangular porém, com o ápice arredondado. Como a peça anterior, apresenta sulcos em ambos os antímeros, na região de inserção da glândula junto às habênulas.

12) Fêmea, Cocker spaniel, 8 anos, 13 quilos - a pineal apresentou formato cônico, tendendo a glossóide (em relação à língua humana). Em vista dorsal, sua superfície é côncava e triangular, porém com o ápice arredondado. 
Quanto ao perímetro, a análise das pineais, em vista dorsal, demonstrou que este variou de 4,52 $\mathrm{mm}$ a 9,69 $\mathrm{mm}$, tendo média de $6,46 \mathrm{~mm}$ e mediana de $6,50 \mathrm{~mm}$ (Tabela 3).

\subsection{Microscopia}

A análise microscópica revelou dois tipos celulares presentes no órgão: pinealócitos e células da glia (possivelmente astrócitos). Os pinealócitos predominaram, estando presentes em todo o parênquima glandular e com maior concentração à medida que se caminha em direção ao centro e à base da glândula. Mostram face aberta, com núcleos grandes, basofílicos, sendo alguns claros e outros mais escuros. A cromatina é granulosa com nucléolo bem evidente, e o citoplasma tem coloração acidófila. Os pinealócitos demonstraram, em alguns casos, disposição tendendo a formar um ácino e, em outros casos formaram arranjo em forma de cordão (Figura 4).

Observou-se a presença de neuróglia, com células com núcleos escuros (mais escuros que dos pinealócitos), contendo cromatina condensada e citoplasma acidófilo.

Há uma cápsula de tecido conjuntivo (Figura 3) que reveste a pineal, com característica delicada sugerindo que ela seja formada pela pia-máter. Esta quando analisada na região da base da glândula, revela um epitélio prismástico, colunar ou cilíndrico com a presença de cílios que estão voltados para o recesso 
pineal, que está em comunicação com o terceiro ventrículo, e à medida que se desloca em direção ao ápice da epífise, este epitélio torna-se cúbico, tendendo a pavimentoso.

Em todas as glândulas pineais analisadas não foram encontrados depósitos de material calcáreo, as chamadas concreções calcáreas, areia cerebral ou acervuli.

Vasos sangüíneos foram encontrados dentro e fora do parênquima glandular, havendo um predomínio destes nas regiões mais superficiais da pineal.

Em 2 (25\%) das 8 pineais analisadas histologicamente, encontramos pequenas regiões com manchas de coloração castanho escuro que possivelmente são referentes a pigmentos de melanina (figura 5). 


\section{DISCUSSÃO}

Em nossas primeiras dissecações, surpreendeu-nos o pequeno tamanho da glândula pineal, em todos os casos. Surpreendeu-nos, também, o fato de encontrarmos glândulas muito pequenas em encéfalos de cães de grande porte e, por outro lado, glândulas não tão pequenas em encéfalos de cães de pequeno porte. Tivemos então a curiosidade de avaliar as dimensões de cada pineal (comprimento, largura e perímetro) e de cada encéfalo correspondente (comprimento e largura) para confrontá-las estatisticamente. Uma vez que não obtivemos dados na literatura consultada, que nos esclarecesse a respeito, buscávamos verificar a existência ou não de correlação entre dimensões da pineal e do respectivo encéfalo.

A análise efetuada revelou que as dimensões da pineal do cão não possuem relação com o tamanho do encéfalo, o que já havíamos observado, durante as dissecações. Provavelmente isso ocorra pelo fato da pineal estar envolvida com um grande número de fatores que não foram foco do nosso estudo, mas que abrem caminho para novos trabalhos, como por exemplo, idade dos animais, sexo, período reprodutivo das fêmeas, condições de manejo, alterações hormonais, raça e mesmo estados enfermos.

Quanto à análise dos aspectos macroscópicos, as pineais mostraram-se localizadas na região de encontro das habênulas, na porção mais caudal do teto do III ventrículo, com direcionamento (da base para o ápice) orientado em sentido dorso-caudal. Estas observações quanto à localização da glândula, estão de acordo com o relatado em tratados de medicina humana e veterinária, por autores 
como Bruni e Zimmmerl (1935), Dyce, Sack e Wensing (1987), Erhart (1968), Hullinger (1993), Machado (1993), Venzke (1986), e outros. Quanto à coloração, ela variou entre bege e marrom-acinzentado, sendo que sua consistência apresentou-se gelatinosa em todas as pineais analisadas. A forma tridimensional das epífises respeitou um padrão cônico e muitas vezes tendeu a glossóide (em relação à língua humana). Em vista dorsal, as pineais revelaram uma forma triangular ou semelhante a "ponta de lança". Esses dados são corroborados quando comparados com os de autores que estudaram a pineal do cão, como Blin e Maurin (1956) os quais relatam que a glândula pineal nos cães é muito pequena e por muito tempo fora ignorada pelos autores, nesses animais. É de forma piramidal e gelatinosa. Quanto à coloração, estes mesmos autores comentam que ela é de transparente a rósea, o que não está em concordância com nossos achados; talvez isso se deva ao fato de termos esperado a fixação do material em solução de formol a $20 \%$, para posteriormente realizarmos a análise macro e mesoscópica. Não apenas devido a isso, mas há fatores outros já citados que podem ter influenciado nessa coloração. Além do mais, os autores anteriores citados não comentam se sua análise fora feita após fixação do material ou a fresco. Quanto ao comprimento e largura da pineal, os autores comentam que ela possui respectivamente $4 \mathrm{~mm}$ e $3 \mathrm{~mm}$. Isso difere também de nossos achados, em que o comprimento da pineal teve média de $2,04 \mathrm{~mm}$ e mediana de $1,97 \mathrm{~mm}$; a largura apresentou média de 1,78 mm e mediana de 1,69 mm. Assim sendo, quando confrontamos nossos dados com os de autores como Blin e Maurin (1956), notamos que as pineais de nossos estudos apresentaram-se aproximadamente duas vezes menores. Quando comparamos em relação aos 
dados de Zach (1960 apud VOLLRATH, 1981, p. 17), verificamos que quanto ao comprimento, as epífises dos cães envolvidos em nosso trabalho mostraram-se iguais ou menores e quanto à largura, revelaram-se maiores quanto ao comprimento.

Ellsworth, Yang e Ellsworth (1985), em trabalho intitulado The Pineal Body of the Dog, não direcionaram seus estudos para as dimensões da pineal, entretanto ressaltam que ela variou em tamanho nos nove cães estudados e que o diâmetro desta foi menor ou igual a $1 \mathrm{~mm}$, divergindo assim dos dados exibidos por Hullinger (1993) no tratado intitulado Evans-Miller's Anatomy of the dog e dos achados de outros autores como Venzke e Gilmore 1940 e Zach 1960. Quando confrontamos nossos resultados com o de Ellsworth, Yang e Ellsworth (1985), embora não tenhamos mensurado o diâmetro das pineais, e sim seu perímetro, notamos que as epífises dos cães de nosso estudo, possuem diâmetro provavelmente maior que o acima relatado; talvez isso se deva ao fato destes autores terem utilizado somente cães da raça Beagle, filhotes e também pelo fato dos animais terem sido confinados de junho a agosto num laboratório climatizado. Quanto ao posicionamento da pineal, Blin e Maurin (1956) propõem uma classificação baseada no posicionamento desta em relação ao esplênio do corpo caloso, podendo ser, portanto: supracalosa, subcalosa e pós-calosa. A dos cães envolvidos em nosso estudo mostrou-se subcalosa, um dado que corrobora o encontrado pelos autores citados, pois estes relatam que a pineal dos carnívoros e dos primatas é subcalosa. Já na classificação proposta por Vollrath 1981, considera-se que as pineais que são alongadas e demonstram um comprimento em torno de ou ligeiramente maior que duas vezes a maior largura, são 
classificadas como sendo do tipo próximo-intermediário ou $A B$, e que a pineal dos cães pertence a este tipo; nossos dados estão em concordância com a classificação proposta pelo autor em relação à espécie canina.

Oksche (1965) propõe que a glândula pineal deve ser classificada apenas quanto ao seu formato: alongado, cônico ou em forma de pera. Quando confrontamos nossos achados como esta classificação, podemos inferir que nos cães estudados, a pineal mantém um padrão em formato cônico, porém verificamos pela análise mesoscópica efetuada, que grande parte das glândulas demonstrou um formato muito semelhante à língua humana, ou seja, glossóide, não sendo por excelência um cone perfeito.

Erhart (1968), em relação a pineal humana, refere que não existe uma igual à outra, característica também verificada em nosso trabalho. Provavelmente toda essa variação esteja ligada ao funcionamento da pineal, pois ela interage através da melatonina com praticamente todos os tecidos do organismo ao qual ela pertence, lembrando ainda que sua fisiologia é dependente do ciclo de luz e escuridão, ou seja, durante o período noturno há maior produção de melatonina, e durante o dia, maior produção de serotonina. Então, podemos pensar que as condições de manejo e ambiente aos quais o animal está exposto influenciam diretamente o funcionamento da epífise cerebral. Outros fatores já citados e que supostamente podem influir nas características morfológicas deste órgão são: idade, raça, sexo, fase do ciclo reprodutivo, ou mesmo estados patológicos e outros, pois a pineal é na verdade um transdutor neuroendócrino e as pesquisas mais recentes, a exemplo de Hara et al. (2001) em artigo intitulado Melatonin, a pineal secretory product with antioxidant properties, protects against cisplatin- 
induced nephrotoxicity in rats, tem demonstrado que o hormônio melatonina está envolvido em muitos processos fisiológicos. Lembrando então o postulado de que a forma se reflete à função, dificilmente uma pineal será igual à outra.

Em relação às pesquisas em outras espécies, citamos o trabalho de HolandaBarros (2002) que estudou a pineal de 30 serpentes, sendo 15 jararacas ( $B$. jararaca) e 15 cascavéis (C. durissus). O autor relata que a epífise é uma estrutura dorsal, mediana, ovóide, de coloração cinzenta ou castanho-escura, situada na região parietal do diencéfalo. Quando confrontamos essas informações com nossos dados, verificamos divergência quanto à forma (ovóide), que nos cães é de cônica a glossóide (em relação à língua humana). Também quanto à coloração, considerando que o olho do observador influencia os resultados, talvez não possamos valorizar as diferenças registradas entre os dados dos autores consultados e os nossos. Este posicionamento dorsal e a forma ovóide das pineais nesses répteis, provavelmente estejam relacionados com a ausência de um córtex cerebral mais desenvolvido e que venha a recobrir a glândula, como ocorre nos cães, tornando-a uma estrutura subcalosa, localizada no centro do encéfalo. Ainda, devemos pensar que as variações na coloração possam ser peculiares à espécie ou devido a fatores outros já comentados.

Silvino et al. (1992), estudando 30 cotias douradas (Dasyprocta aguti), relatam que a epífise cerebral nesses animais apresentou-se alongada, de cor acinzentada ou castanho-escuro, situada sobre o teto do terceiro ventrículo, entre os colículos rostrais, ocupando o sulco entre eles. Branco et al. (1997), em estudo envolvendo a pineal de 19 capivaras (Hydrochoerus hydochoeris), descrevem que estas são de coloração branco perolada, às vezes ligeiramente acastanhada, sendo 
bastante desenvolvida nesses animais. Situa-se no teto do terceiro ventrículo, assentando-se rostralmente aos colículos rostrais e insinuando-se entre o cérebro e o cerebelo. A glândula, nesses animais, apresenta-se constituída por três partes distintas: um ápice mais dilatado, o qual insinua-se entre os hemisférios cerebrais e o cerebelo, ultrapassando os limites cerebrais; um corpo cilíndrico, alongado, e a base do órgão. Quando comparamos nossos achados com os dos autores que acabamos de citar, verificamos que no caso das cutias há concordância com o que encontramos nos cães, quanto à localização e também quanto à coloração das pineais. Já no caso das capivaras, o formato da pineal é totalmente diferente daquele encontrado nos cães de nosso trabalho. Quanto à coloração, também há divergência se confrontarmos com as de cor branco-perolada e concordância nas situações em que a pineal mostrou coloração ligeiramente acastanhada.

Assim sendo, podemos verificar que a maioria das espécies envolvidas nesta discussão, em maior ou menor proporção, apresentou em comum o posicionamento, a localização na linha mediana do encéfalo e a coloração que se enquadra num tom castanho ou ligeiramente amarronzado, chegando a ter uma mistura entre marrom-acinzentada-esbranquiçada.

Quanto aos aspectos microscópicos abordados, as pineais dos cães envolvidos em nosso estudo, foram acondicionadas para fixação em solução de McDowell e como método de coloração foi empregado o da hematoxilina-eosina. A análise histológica demonstrou a presença de pinealócitos, e células da glia, estas em menor número e que, segundo a literatura, são provavelmente astrócitos; porém somente poderíamos afirmar isso se tivéssemos utilizado coloração específica para evidenciar este tipo celular. Além disso, os linfócitos na pineal, sob a 
coloração de H.E., aparecem de forma e cor semelhantes às dos astrócitos, ficando muito difícil a diferenciação entre estes dois tipos celulares quando esta coloração é empregada. Em alguns casos, os pinealócitos dispuseram-se na vizinhança de vasos sangüíneos formando, em seguimentos longitudinais desses vasos uma espécie de cordão, e em outros casos, os pinealócitos se agruparam originando uma estrutura semelhante a ácino, independente de estarem próximos ou não a vasos. Essa disposição provavelmente se deva à função secretora que a pineal possui, lembrando que ela produz e libera o hormônio melatonina, o que lhe conferiu a característica de glândula, por alguns autores. Porém, não podemos deixar de ressaltar que grande parte dos pinealócitos encontra-se de forma difusa, na pineal.

Confrontando nossos dados com a literatura, em relação à glândula pineal humana, podemos citar, em concordância com nossos achados, dados relatados por autores como Szymonowicz e Krauze (1935), para os quais as características estruturais da epífise humana revelam uma função secretora; está presente uma cápsula de tecido conjuntivo revestindo o órgão e emitindo septos para o interior de seu parênquima, promovendo uma divisão da glândula em lóbulos de tamanhos desiguais. Esta lobulação resultante da presença destes septos, não foi notada nas pineais estudadas por nós, porém pinealócitos apresentaram-se em maior quantidade na região central e da base das epífises. Os autores relatam que as células nervosas (entendemos tratar-se de células da glia) estão presentes em menor número e são astrócitos. Notamos também células de núcleo muito escuro, que sugerimos serem astrócitos, porém como já fora discutido, não podemos afirmar que sejam estes tipos celulares sem estudos mais específicos. Estes 
autores citam também a presença de concreções calcáreas na pineal humana. Nos cães de nosso trabalho, estas estruturas não foram encontradas, mesmo naqueles que aparentavam idades mais avançadas, ou seja, acima de 8 a 10 anos, uma vez que essas concreções tendem a aumentar de acordo com a idade. Gartner e Hiatt (1999) descrevem que a epífise humana é revestida pela piamater, formando uma cápsula da qual partem septos que dividem a mesma em lóbulos incompletos. As pineais observadas em nosso estudo apresentaram uma cápsula de característica delicada, sugerindo fortemente que seja a pia-mater; já a presença de vários septos a partir desta, não foi uma característica observada, pois evidenciamos pequena quantidade deles, dispostos aparentemente de forma aleatória. Os mesmos autores relatam que as células parenquimatosas da glândula são constituídas principalmente por pinealócitos e células intersticiais; os pinealócitos são células fracamente basófilas, com um ou dois prolongamentos longos, cujas dilatações terminais se aproximam de capilares ou ocasionalmente de outras células parenquimatosas. Seus núcleos são esféricos e possuem um único nucléolo proeminente. No relativo às células instersticiais, acredita-se que sejam da neuróglia, semelhantes aos astrócitos e encontram-se espalhadas entre os pinealócitos. Dessas características descritas, todas elas foram observadas nas pineais de nosso estudo.

Yong e Heath (2001), além de citarem a presença dos pinealócitos e células da neuróglia na pineal humana em seu tratado, relatam também que os pinealócitos são neurônios altamente modificados dispostos em aglomerados e cordões circundados por uma rica rede de capilares fenestrados, possuem citoplasma granular e muitos prolongamentos altamente ramificados, alguns dos quais 
terminam junto aos vasos sangüíneos ou sobre eles. Esta última disposição, os aglomerados e os cordões de pinealócitos foram também características observadas nas epífises dos cães envolvidos em nosso estudo. Possivelmente estas disposições que muitas vezes estão próximas a vasos sangüíneos, devamse à característica de um tecido que está secretando algo, no caso, a melatonina que é produzida na pineal. Os autores ainda comentam que as células da neuróglia são semelhantes aos astrócitos do resto do SNC. Estão dispersas entre os aglomerados de pinealócitos e em associação a capilares. Mais uma vez, essas descrições nos permitem sugerir com mais segurança que as células da neuróglia observadas nas epífises avaliadas em nosso trabalho, sejam astrócitos. Junqueira e Carneiro (1999) comentam que na pineal humana predominam 2 tipos celulares, os pinealócitos e os astrócitos. Os primeiros apresentam-se à coloração de H.E. com o citoplasma claro e grandes núcleos esféricos. Constituem $95 \%$ das células da pineal; entre eles observam-se núcleos alongados e mais fortemente corados que pertencem aos astrócitos, que constituem $5 \%$ do parênquima da pineal. Citam os autores, que acervuli cerebri ou areia cerebral é o nome dado às concreções de fosfato e carbonato de cálcio encontradas normalmente na pineal do adulto e que aumentam de número com a idade. Já comentamos que nos cães de nosso estudo estas concreções não foram encontradas, sendo difícil estabelecer quais as eventuais razões dessa ocorrência; pinealócitos e células de núcleo escuro (possivelmente astrócitos) foram encontradas, além de células com núcleo semelhante em coloração ao dos pinealócitos, mas com forma diferente a dos pinealócitos. Talvez sejam pinealócitos em fase funcional mais ou menos 
ativa, ou talvez se trate de um outro tipo celular, que desconhecemos. Para melhor esclarecer estas dúvidas, um estudo de microscopia eletrônica seria mais fiel. Bargman (1961), em seu tratado sobre histologia e anatomia microscópica da glândula pineal em humanos, descreve a presença do recesso pineal do terceiro ventrículo, insinuando-se na base da pineal, o que pôde ser observado em nosso estudo também. O mesmo autor relata também que às vezes observam-se territórios semelhantes a lóbulos no interior do órgão, sendo o tecido epifisário específico formado por células pineais ou pinealócitos, além de células e fibras gliais (predominando os astrócitos). Cita também este autor, a presença de concreções calcáreas que aumentam com o avanço da idade.

No tratado de Trautmann e Fiebiger (1950), em relação ao aspecto histológico da glândula pineal nos animais domésticos, eles descrevem que ela está envolta por um tecido conjuntivo que envia prolongamentos ou trabéculas para o interior do órgão, formando uma rede incompleta no centro. Acompanhando esta rede há células gliais e agrupamentos de células pineais, sendo que com freqüência se observa um pigmento pardo enegrecido entre as células e dentro delas, especialmente nos animais velhos. Há também a presença de concreções calcáreas e corpos amilóides, sendo que a glândula pineal não é rica em vasos sangüíneos. Confrontando nossos achados com os desses autores, notamos em concordância, a presença de pinealócitos, células da glia e de pigmentos pardoenegrecidos, que provavelmente sejam melanina; em discordância, notamos a presença de células de núcleo escuro, que são células da neuróglia, e não notamos a presença de concreções calcáreas. Como os autores não informam, em seus estudos nos animais domésticos, que espécies abrangeram, não temos 
condições de afirmar se as características mencionadas aplicam-se realmente a todos os animais domésticos.

Em relação aos tratadistas que abordam o aspecto da microscopia de luz no cão, citamos Hullinger (1993) que, em sua obra intitulada Evans/Miller's anatomy of the dog, descreve que as células presentes na glândula pineal desta espécie são denominadas de endocrinócitos pineais, encontrando-se em maior número quando comparadas às células de sustentação ou gliócitos centrais. A piamater recobre toda a glândula e há uma delicada cápsula que possui moderada quantidade de tecido conjuntivo e envia septos e trabéculas para o interior da pineal. Acompanhando estas estruturas, cursam os vasos sangüíneos e fibras simpáticas pós-ganglionares. Em nosso estudo, observamos estas mesmas características, porém como já citamos, a cápsula que recobre a pineal provavelmente é oriunda da pia-mater, e esta possui um epitélio que varia de colunar/prismático a pavimentoso, à medida que caminha da base para o ápice da epífise cerebral.

Banks. (1986), em seu livro sobre histologia veterinária aplicada, descreve que a pineal nos animais domésticos é coberta por um tecido conjuntivo da pia-mater, e que septos e lobulações do órgão são acompanhados por este mesmo tipo tecidual. Em relação aos componentes celulares, os autores relatam a presença de pinealócitos e astrócitos, podendo-se eventualmente encontrar fibroblastos, plamócitos, mastócitos e macrófagos. Os pinealócitos são o tipo celular predominante e possuem um núcleo aberto, grande e redondo, estando situado em um citoplasma acidofílico. Estas características foram igualmente observadas nas pineais dos cães que nós estudamos, embora muitas vezes alguns núcleos não se apresentaram com forma totalmente arredondada. Os autores ainda 
comentam que os astrócitos são típicos e estão situados entre o tecido vascular e os pinealócitos mencionando também a presença de concreções calcáreas. Em relação aos primeiros, nós encontramos células da glia que sugerimos serem astrócitos e a localização destes coincide com o que os autores citam. Já em relação às concreções calcáreas, elas não foram observadas em nosso material. Dellman e Brown (1982), em tratado de histologia veterinária, comentam que o corpo pineal dos mamíferos mostra-se como um órgão sólido, parenquimatoso ou folicular, circundado por uma delgada camada de tecido conjuntivo frouxo. Quanto à celularidade, eles descrevem a presença de astrócitos circundando os pinealócitos e mantendo um contato com a lâmina perivascular, separando assim a maioria dos pinealócitos no espaço perivascular. Já foi citado que encontramos os tipos celulares acima descritos, porém quanto à consistência da glândula pineal, nos cães ela apresentou-se gelatinosa, divergindo do que esses autores relatam sobre os mamíferos.

Ellsworth, Yang e Ellsworth (1985), em seu trabalho intitulado The Pineal Body of the Dog, estudaram as pineais de 9 cães da raça beagle através de histologia empregando como método de coloração a hematoxilina-eosina, e descreveram a presença de células ependimárias observadas usualmente na margem, e pinealócitos e células da glia no centro da pineal. Em algumas glândulas, encontrou-se fazendo parte da composição da cápsula, epitélio colunar ou cubóide de um lado e epitélio simples do outro. Estes mesmos autores comentam que não há lobulações e sim grupos de pinealócitos dando origem a formações não bem definidas, semelhantes a ácinos. Estas estruturas são rodeadas por espaços de tecido conjuntivo. Ao redor da periferia da glândula há pequenas arteríolas e no 
interior há predomínio de capilares. Os processos citoplasmáticos das células da glia e pinealócitos encontram-se próximos aos vasos sangüíneos. As células parenquimatosas não possuem formato uniforme e contém um núcleo vesicular de vários tamanhos com cromatina dispersa, porém de aspecto granular em alguns casos. O citoplasma destas células possui uma coloração rosa claro, com prolongamentos às vezes evidentes. Nucléolo único fora usualmente identificado, embora em alguns casos seja duplo. Estes autores ainda descrevem que alguns núcleos escuros foram observados podendo ser linfócitos ou células da glia. Comentam que trabalhos prévios não relataram a presença de concreções calcáreas na glândula pineal do cão e que eles também não encontraram esta estrutura. Como aspecto importante, ressaltam que o tamanho da pineal variou individualmente nos 9 cães estudados. Em nosso estudo, os achados corroboram as citações desses autores, e ressaltamos o fato dos pinealócitos encontrarem-se dispersos por toda a glândula e tendendo a uma maior concentração na região do centro para a base das pineais avaliadas, assim como as células da glia.

Calvo et al. (1988) realizaram trabalho com 12 cães sem raça definida, sendo todos adultos e de ambos os sexos, estudando a estrutura e ultra-estrutura das células da pineal do cão, tendo como principal objetivo, avaliar o tipo de pigmento presente nelas. Estes autores mencionam que em 1974 Quay relatou poder existir três tipos de pigmentos na pineal dos mamíferos: melanina, lipofuscina e hemosiderina. Para microscopia de luz, utilizaram o método de coloração de prata de Masson Fontana, e também se utilizou tratamento com hidróxido de hidrogênio e ácido peracético. Neste estudo, encontrou-se pigmento em todas as pineais analisadas e confirmou-se que estes eram de melanina. Nas pineais envolvidas 
em nosso trabalho, notamos também a presença de grânulos de coloração castanho escuro ou marrom escuro, que sugerimos serem pigmentos de melanina. Porém, em relação à incidência, nossos dados divergem dos achados citados por esses autores, pois apenas duas das oito pineais utilizadas para microscopia de luz, apresentaram esta estrutura.

Quanto aos estudos envolvendo microscopia de luz em outras espécies, destacamos o de Holanda-Barros (2002), em 30 serpentes, sendo 15 jararacas e 15 cascavéis; o de Silvino (1999) em 12 ratos e 12 coelhos, todos machos; o de Carvalho (1997) em 12 búfalos e o de Branco et al. (1997), em 19 capivaras. Notamos que, em relação aos tipos celulares encontrados por estes autores, não houve divergência em comparação aos encontrados nos cães e, desta forma, podemos pensar que o modelo que a epífise cerebral vem apresentando na escala evolutiva ao longo do tempo, não tem sofrido grandes modificações, ou seja, ele tem mostrado um determinado padrão, conforme fora comentado neste capítulo. Entretanto, a glândula pineal ainda é uma estrutura desconhecida, em muitos aspectos, haja vista a maneira peculiar como se apresenta nas diferentes espécies. Assim sendo, muitas das perguntas que ainda são feitas sobre a pineal, demandam estudos, pois os conhecimentos anatômicos desta estrutura, são fundamentais para o real entendimento de seu papel funcional. 


\section{CONCLUSÕES}

Pelo que acabamos de expor, julgamos poder concluir que:

- A glândula pineal de todos os cães estudados apresentou-se situada em relação à região posterior do teto do III ventrículo em correspondência ao plano mediano, inserindo-se, por sua base, na região das habénulas (vista dorsal). Têm forma cônica ou glossóide (relativamente à língua humana) sendo que seu corpo e ápice tendem em sentido dorso-caudal descrevendo curvatura de concavidade ventral, em direção aos colículos rostrais.

- O comprimento das glândulas pineais variou de 1,53 mm a 2,96 mm, com média de 2,04 e mediana de $1,97 \mathrm{~mm}$, enquanto que para sua maior largura foram registrados valores entre $1,38 \mathrm{~mm}$ e $2,39 \mathrm{~mm}$, com média de 1,78 $\mathrm{mm}$ e mediana de 1,69 mm. Não foi encontrada, estatisticamente, correlação dessas variáveis com o tamanho (comprimento e largura) dos encéfalos correspondentes.

- As glândulas pineais, em relação à coloração, demonstraram uma variação entre bege e castanho-acinzentado;

- Analisadas quanto à forma, disposição espacial, cor e dimensões, as pineais exibem diferenças individuais de forma a não termos registrado uma igual à outra;

- As glândula pineais dos cães estudados inserem-se no tipo intermédio-proximal ou AB, da classificação de Vollrath (1981);

- Histologicamente as glândula pineais dos cães estudados demonstraram um modelo típico dos mamíferos contendo uma delicada cápsula que emite septos ou trabéculas para o interior do órgão; pinealócitos com núcleo arredondado podendo variar para ovóide, basófilos, com cromatina dispersa e em maior número; células 
da glia com núcleos escuros e variando de redondo a ovóide; aglomerados de coloração castanho ou marrom escuro (provavelmente pigmentos de melanina); identificação do recesso pineal;

- Não foram observadas concreções calcáreas (areia cerebral ou acervuli) em todas as glãndulas pineais analisadas macro, meso e microscopicamente. 


\section{REFERÊNCIAS}

ADAM, W. S.; CALHOUN, M. L.; SMITH, E. M.; STINSON, A. W. Microscopic anatomy of the dog: a photografic atlas. Springfield: Charles C. Tomas, 1970. p. 292.

ANDERSON, W. D. Atlas of canine anatomy. Malvern: Lea \& Fiebiger, 1994. p. 1230.

BANKS, W. J. Applied veterinary histology. 2nd. ed. Baltimore: Williams \& Wilkins, 1986. p. 473-474.

BARGMANN, W. Die epiphysis cerebri. In: VON MÖLLENDORFF, W. Handbuch der mikroskopischen anatomie des menschen. Berlin: Springer Verlag, 1943. v. 6 , n. 4, p. 309-505.

BINKLEY, S. The pineal - endocrine and nonendocrine function. Englewood Cliffs, Prentice Hall, 1988.

BLIN, P. C.; MAURIN, C. Anatomie macroscopique de l'epiphyse des mammifères domestiques. Recueil Medicine Véterinaire, v. 132, p. 36-52, 1956.

BRANCO, E. R.; GUIMARÃES, A.; MIGLINO, M. A.; DIDIO, L. J. A.; NURMBERGER, R.; SOUZA, W. M. Pesquisa anatômica da glândula pineal em capivaras (Hydrochoerus hydrochoeris). Brazilian Journal of Veterinary Research and Animal Science, v. 34, n. 4, p. 191-195, 1997.

BRUNI, A. C.; ZIMMERL, U. Anatomia degli animali. Milano: Francesco Vallardi, 1947. v. 2, p. 268.

CALVO, J.; BOYA, J.; GARCIA-MAURIÑ, J. E.; LOPEZ-CARBONELL, A. Structure and ultrastructure of the pigmented cells in the adult dog pineal gland. Journal of Anatomy, v. 160, p. 67-73, 1988.

CARVALHO, A. F. Histologia e Histometria da glândula pineal de búfalo (Bubalus bubalis - Lineaus, 1758). 1997. 117 f. Dissertação (Mestrado em Qualidade e Produtividade Animal) - Faculdade de Zootecnia e Engenharia de Alimentos da Universidade de São Paulo, Pirassununga, 1997.

DELLMANN, H. D.; BROWN, E. M. Histologia veterinária. Rio de Janeiro: Guanabara Koogan, 1982. p. 305.

DYCE, K. M.; SACK, W. O.; WENSING, C. J. G. Textbook of veterinary anatomy. 2nd. ed. Philadelphia: W. B. Saunders, 1987. p. 207. 
ELLSWORTH, A. F.; YANG, T-J.; ELSSWORTH, M. L. The Pineal Body of the Dog. Acta Anatomica, v. 122, p. 197-200, 1985.

ERHART, E. A. Neuroanatomia, 4ª ed. São Paulo: Atheneu,1968. p. 47.

FAVALLI, N. Nozioni comparate di anatomia e fisiologia degli animale rurali. Torino: Unione Tipográfico,1931. p. 147.

GOLDZIEHER, M. A. A Glândula Pineal. In: GOLDZIEHER, M. A Endocrinologia - as glândulas endócrinas. Rio de Janeiro: Guanabara, 1945. p. 355 - 356.

HARA, M.; YOSHIDA, M.; NISHIJIMA, H.; YOKOSUKA, M.; LIGO, M.; OHTANIKANEKO, R.; SHIMADA, A. ; HASEGAWA, T.; AKAMA, Y.; HIRATA, K. Melatonin, a pineal secretory product with antioxidant properties, protectsagainst cisplatininduced nephrotoxicity in rats. Journal of Pineal Research, v. n. 30, p. 129-138, 2001.

HOLANDA-BARROS, P. M. Estudo da pineal em jararacas (B. jararaca) e cascavéis (C. durissus). 2002. 82 f. Dissertação (Mestrado em Anatomia dos Animais Domésticos) - Faculdade de Medicina Veterinária e Zootecnia, Universidade de São Paulo, São Paulo, 2002.

HULLINGER, D. L. The Endocrine System. In: EVANS, H. E.; MILLER, M. E. Evans-Miller's anatomy of the dog. 3th ed. Philadelphia: W. B. Saunders, 1993. p. $572-573$.

JUNQUEIRA, L. C.; CARNEIRO, J. Histologia básica. Rio de Janeiro: Guanabara Koogan, 1999. p. 353.

KAPPERS, A.; HUBER, C.; CROSBY, E. C. The comparative anatomy of the nervous system of vertebrates, including man. New York: Hafner Publishing, 1960. v. 2, p. 1100-1101.

KITAY, J. I.; ALTSCHULE, M. D. The pineal gland - a review of the physiologic literature. Cambrige: Harvard University Press, 1954.

LERNER, A. B.; CASE, J. S.; TAKAHASHI, Y.; LEE, T. H.; MORI, W. Isolation of melatonin, the pineal gland factor that lightens melanocytes. Journal of American Chemestry Society, n. 80, p. 2587, 1958.

LERNER, A. B. The Pineal. In: WILLIAMS, R. Textbook of endocrinology. $3^{\text {a }}$ ed Philadelphia: W. B. Saunders, 1962. p. 880.

MACHADO, A. Estrutura e Funções do Subtálamo e do Epitálamo. In: Neuroanatomia funcional. $2^{a}$ ed. São Paulo: Atheneu, 1993. p. 238.

MARY, D. Endocrine System. In: GRAY, H.; GOSS, C. M. Gray's Anatomy. Edinburgh: Churchill Livingstone, 1995. p. 1888 - 1889. 
OLIVEIRA, S. F. Estudo da estrutura da glândula pineal humana empregando métodos de microscopia de luz, eletrônica de varredura, microscopia de varredura por espectrometria de raio-x e difração de raio-x. 1988. $129 \mathrm{f}$. Dissertação (Mestrado em Anatomia Funcional: Estrutura e Ultra-estrutura) Instituto de Ciências Biomédicas, Universidade de São Paulo, São Paulo, 1998.

REITER, J. R. The Mammalian Pineal Gland: Estructure and Function. The American Journal of Anatomy, n. 162, p. 287-313, 1981.

SCHAFFER, E. A.; SYMINGTON, J.; BRYCE, T. H. Quain's elements of anatomy. New York: Longmans \& Green, 1909. p. 228-230.

SILVINO, M. J.; MIGLINO, M. A.; DIDIO, L. A.; HERNANDEZ-BLASQUEZ, F. J. The pineal gland in adult "golden cutia"(Dasyprocta aguti, rodentia, caviomorpha). Revista Chilena de Anatomia, v. 13, n. 2, p. 17-23, 1995.

SILVINO, M. J. Aspectos morfométricos da glândula pineal em ratos e coelhos. 1999. 70 f. Tese (Doutorado em Anatomia dos Animais Domésticos) Faculdade de Medicina Veterinária e Zootecnia, Universidade de São Paulo, São Paulo, 1999.

SZYMONOWICZ, L.; KRAUZE, R. Tratado de histología y anatomía microscópica. Barcelona: Labor, 1935. p. 197-199

TILDEN, A. R.; HUTCHINSON, V. H. Influenceof photoperiod and temperature on serum melatonim in the Diamondback Water Snake (Nerodia rhombifera). General and Comparative Endocrinology, Oklahoma, v. 92, n. 3, p. 347-354, 1993.

TRAUTMAN, A.; FIEBERG, J. Histología y anatomia microscópica comparada de los animales domésticos. Barcelona: Labor, 1942. p. 164-165.

VENZKE, W. G. Endocrinologia do Carnívoro. In: GETTY, R.; ROSENBAUM, C. E.; GHOSHALO, N. G.; HILLMANN, D. Sisson/Grossman Anatomia dos animais domésticos. Rio de Janeiro: Guanabara Koogan, 1986. v. 2, p. 1496.

VOLLRATH, L. The pineal organ. Berlin: Springer-Verlag, 1981. 665 p. 
APÊESDICE 


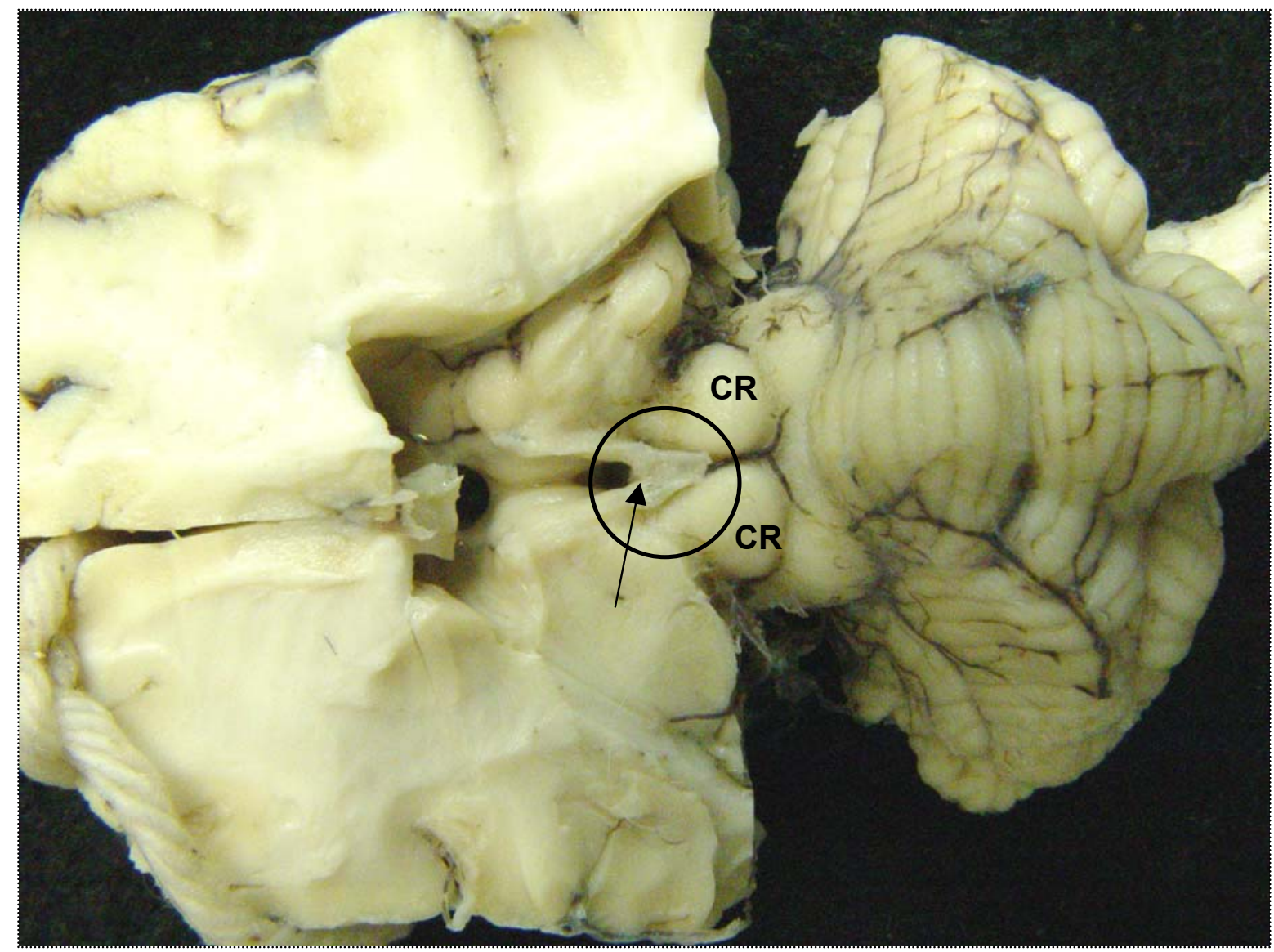

Figura 1 - Fotografia do encéfalo de cão fêmea, da raça cocker spaniel, com aproximadamente 8 anos de idade, pesando $13 \mathrm{~kg}$. Aumento aproximado de 2,6 vezes. Corte longitudinal dos hemisférios cerebrais, em vista dorsal, destacando-se no círculo a glândula pineal, sobre a porção caudal do teto do III ventrículo. De formato triangular, tem a base inserida na região das habénulas $(\rightarrow)$ e o ápice projetado em direção aos colículos rostrais (CR). 


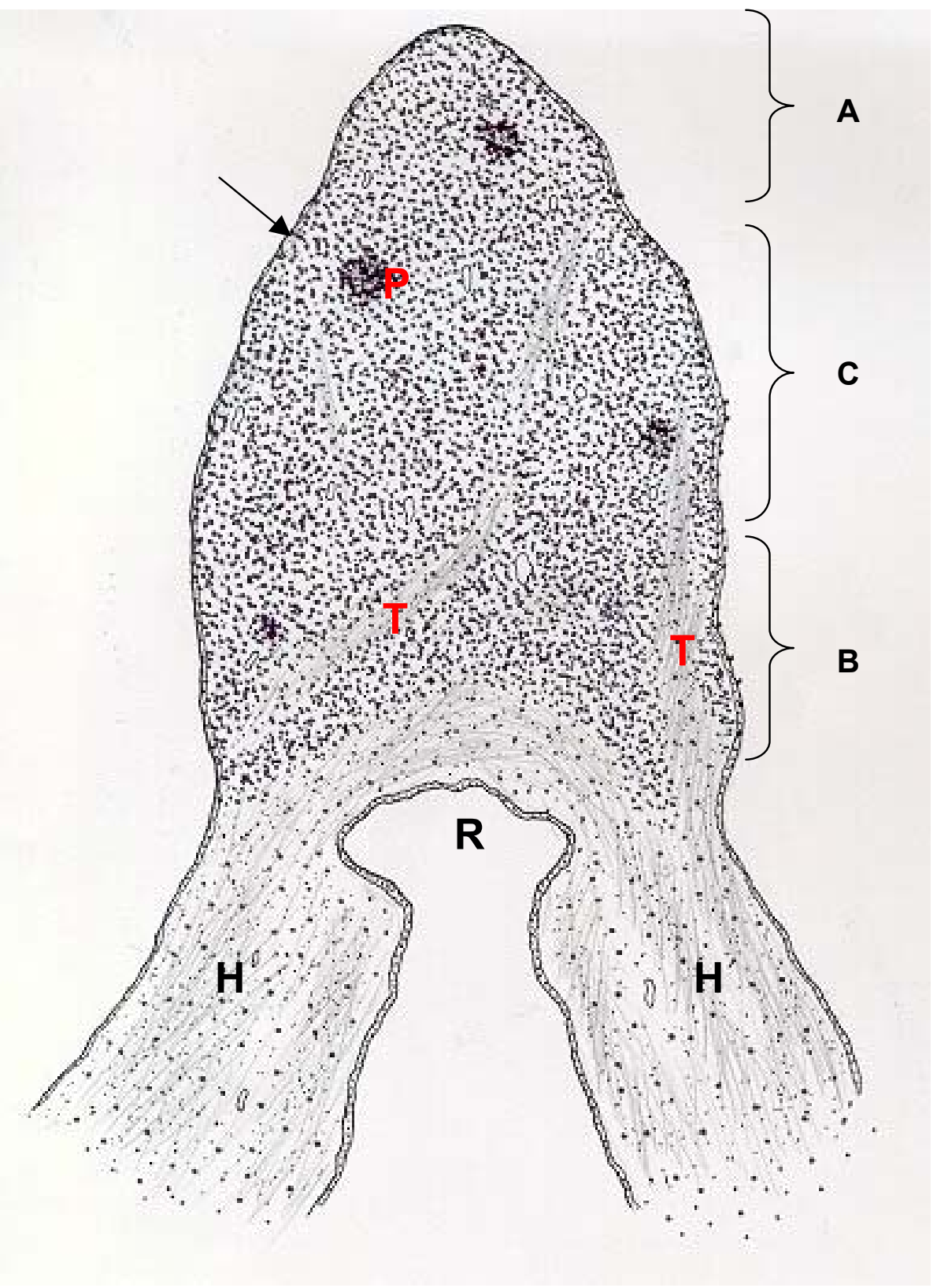

Figura 2 - Esquema representativo da glândula pineal de cão, em corte longitudinal. $R$ - recesso pineal do III ventrículo; B - base, C - corpo e A - ápice da glândula; $\mathrm{H}$ - habênulas; $\mathrm{T}$ - trabéculas ou septos; $\mathrm{P}$ pigmentos; cápsula $(\rightarrow)$. 


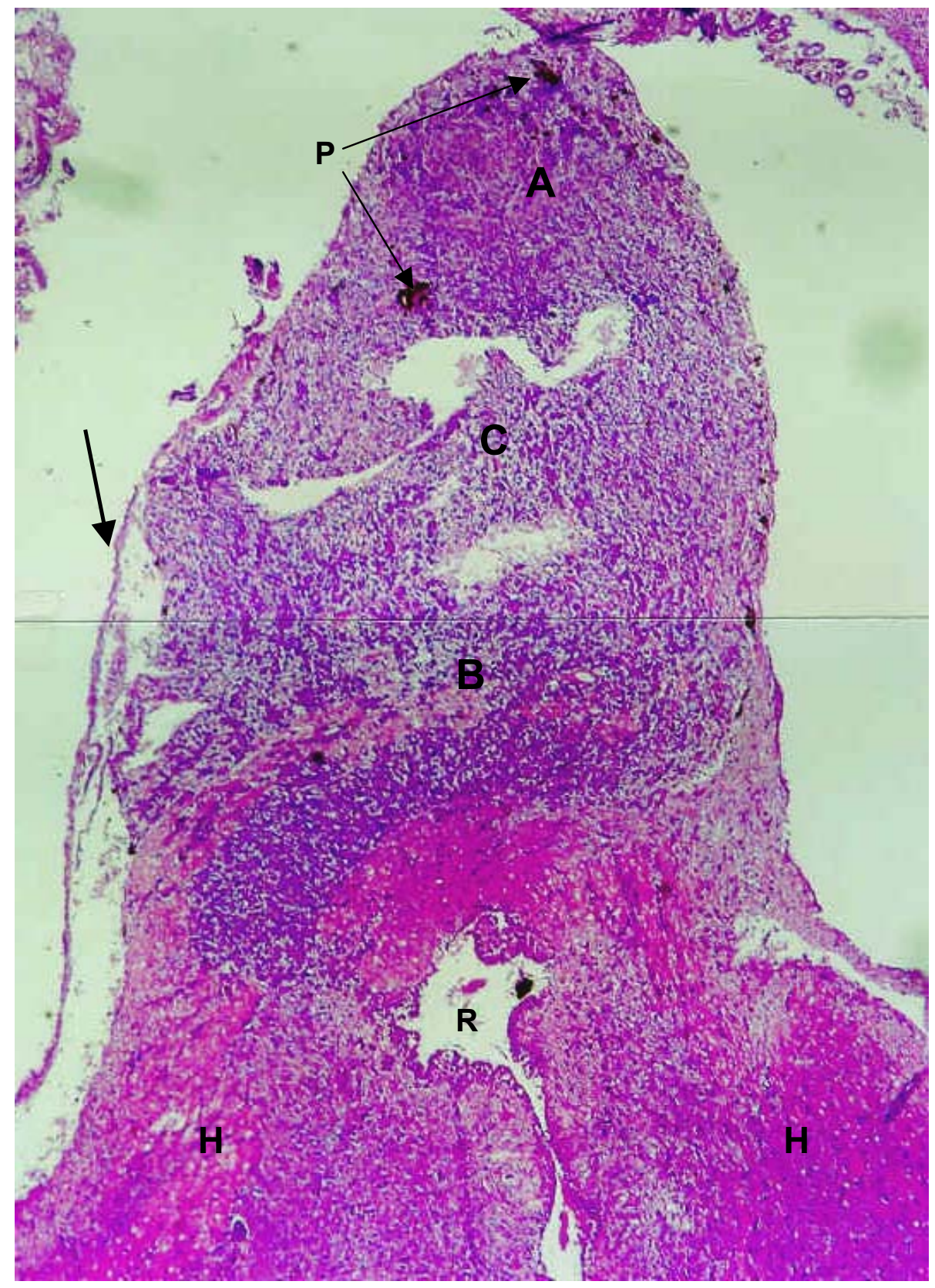

Figura 3 - Fotomicrografia, em corte longitudinal, da glândula pineal de cão, fêmea, SRD, com aproximadamente 3 anos de idade, pesando $25 \mathrm{~kg}$. Aumento de 55 vezes. $R$ - recesso pineal do III ventrículo; $B$ - base, C - corpo e A - ápice da glândula; $\mathrm{H}$ - habênulas; $\mathrm{P}$ - pigmentos; cápsula $(\rightarrow)$. HE 


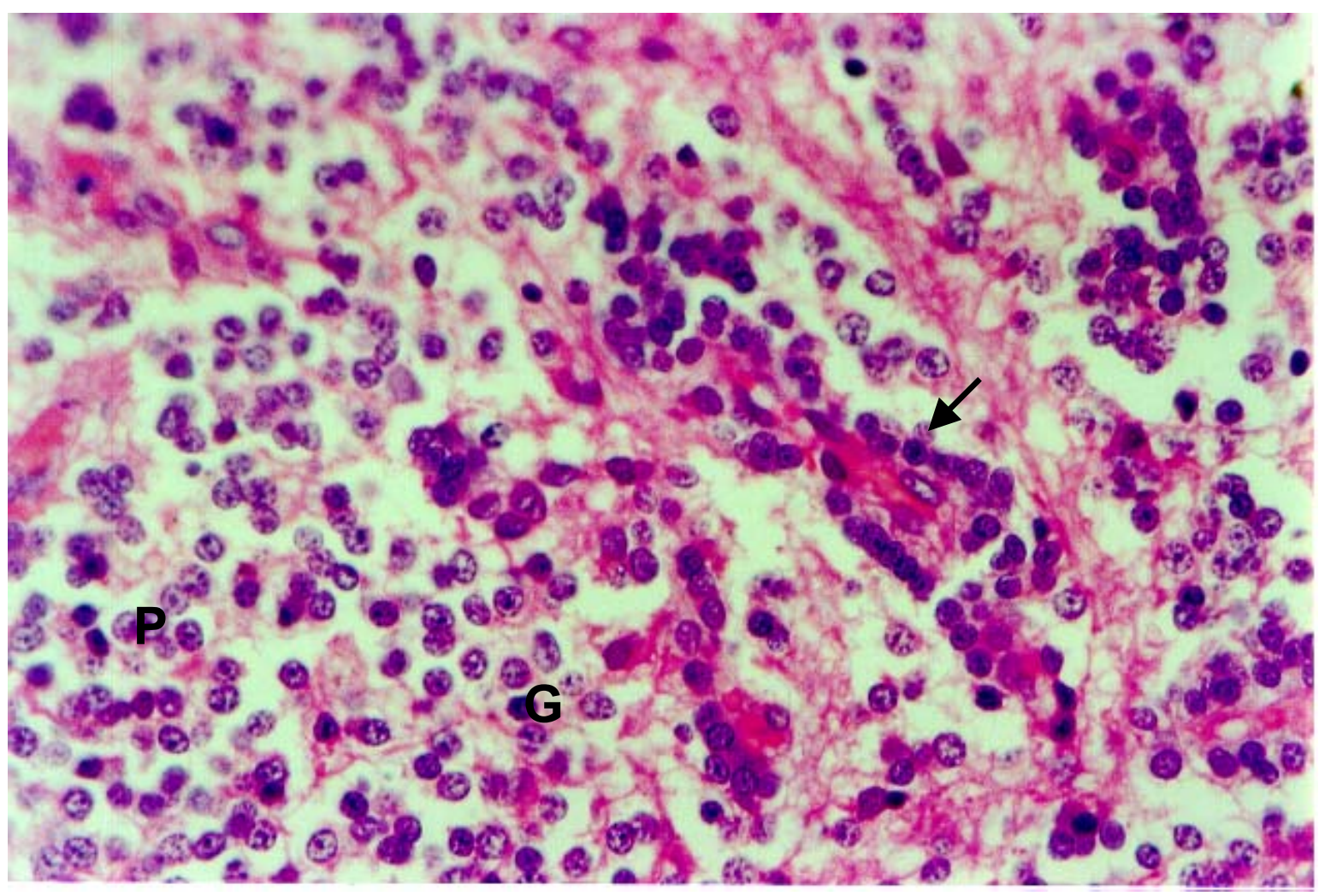

Figura 4 - Fotomicrografia, em corte transversal, de glândula pineal de cadela, SRD, com aproximadamente 13 anos de idade, pesando $11 \mathrm{~kg}$. Aumento de 275,1 vezes. Os pinealócitos $(P)$ mostram-se presentes em todo o parênquima glandular, sendo mais numerosos que as células da glia $(G)$. Os pinealócitos por vezes dispõem-se em arranjo perivascular, em cordão $(\rightarrow)$. HE 


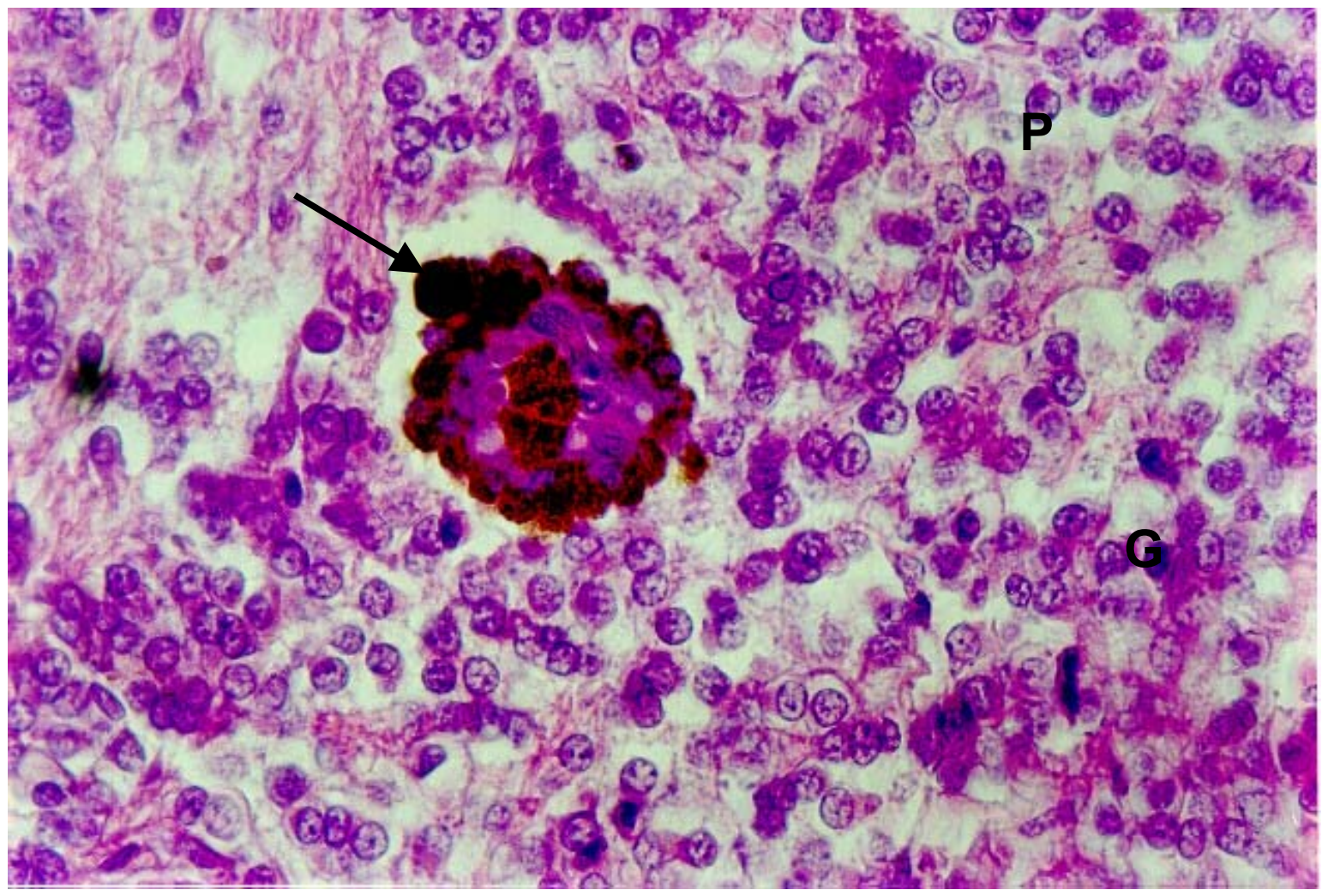

Figura 5 - Fotomicrografia, em corte longitudinal, de glândula pineal de cadela, SRD, com aproximadamente 3 anos de idade, pesando $25 \mathrm{~kg}$. Aumento de 552,3 vezes. Observam-se pinealócitos $(P)$, células da glia $(G)$ e formação com grânulos de pigmentos $(\rightarrow)$. HE 
Tabela 1 - Medidas do comprimento e da largura dos encéfalos dos cães analisados, expressas em milímetros - São Paulo, 2003

\begin{tabular}{ccc}
\hline Observação & CE & LE \\
\hline 1 & 63,00 & 33,35 \\
2 & 68,59 & 36,76 \\
3 & 82,76 & 41,15 \\
4 & 61,09 & 33,74 \\
5 & 73,75 & 37,05 \\
6 & 85,63 & 40,66 \\
7 & 64,56 & 33,46 \\
8 & 60,15 & 31,31 \\
9 & 75,99 & 43,48 \\
10 & 86,27 & 40,18 \\
11 & 54,06 & 32,40 \\
12 & 64,69 & 36,25 \\
\hline média & 70,05 & 36,65 \\
mediana & 66,64 & 36,51 \\
\hline CE = comprimento do encéfalo; LE = largura do encéfalo
\end{tabular}


Tabela 2 - Medidas do comprimento e da largura das glândulas pineais, expressas em milímetros nos cães analisados - São Paulo, 2003

\begin{tabular}{ccc}
\hline Observação & CP & LP \\
\hline 1 & 1,64 & 1,52 \\
2 & 2,20 & 1,60 \\
3 & 1,86 & 1,67 \\
4 & 1,55 & 1,48 \\
5 & 2,24 & 2,09 \\
6 & 1,53 & 1,38 \\
7 & 2,57 & 2,17 \\
8 & 2,08 & 1,87 \\
9 & 2,39 & 1,93 \\
10 & 1,69 & 1,58 \\
11 & 1,84 & 1,71 \\
12 & 2,96 & 2,39 \\
\hline média & 2,05 & 1,78 \\
mediana & 1,97 & 1,69 \\
\hline CP = comprimento da pineal; LP = largura da pineal
\end{tabular}


Tabela 3 - Medidas do perímetro das glândulas pineais, expressas em milímetros, dos cães analisados - São Paulo, 2003

\begin{tabular}{cc}
\hline Observação & PP \\
\hline 1 & 5,70 \\
2 & 6,59 \\
3 & 5,96 \\
4 & 4,52 \\
5 & 6,54 \\
6 & 4,74 \\
7 & 7,39 \\
8 & 5,56 \\
9 & 7,77 \\
10 & 6,46 \\
11 & 6,63 \\
12 & 9,69 \\
\hline Média & 6,46 \\
Mediana & 6,50
\end{tabular}

